San Jose State University

SJSU ScholarWorks

Master's Theses

Master's Theses and Graduate Research

1992

\title{
Feeding habits of the midwater polychaete, Poeobius meseres (Heath, 1930) in Monterey Bay, California
}

Lisa Uttal-Cooke

San Jose State University

Follow this and additional works at: https://scholarworks.sjsu.edu/etd_theses

\section{Recommended Citation}

Uttal-Cooke, Lisa, "Feeding habits of the midwater polychaete, Poeobius meseres (Heath, 1930) in Monterey Bay, California" (1992). Master's Theses. 430.

DOI: https://doi.org/10.31979/etd.7cmx-kjcw

https://scholarworks.sjsu.edu/etd_theses/430

This Thesis is brought to you for free and open access by the Master's Theses and Graduate Research at SJSU ScholarWorks. It has been accepted for inclusion in Master's Theses by an authorized administrator of SJSU ScholarWorks. For more information, please contact scholarworks@sjsu.edu. 


\section{INFORMATION TO USERS}

This manuscript has been reproduced from the microfilm master. UMI films the text directly from the original or copy submitted. Thus, some thesis and dissertation copies are in typewriter face, while others may be from any type of computer printer.

The quality of this reproduction is dependent upon the quality of the copy submitted. Broken or indistinct print, colored or poor quality illustrations and photographs, print bleedthrough, substandard margins, and improper alignment can adversely affect reproduction.

In the unlikely event that the author did not send UMI a complete manuscript and there are missing pages, these will be noted. Also, if unauthorized copyright material had to be removed, a note will indicate the deletion.

Oversize materials (e.g., maps, drawings, charts) are reproduced by sectioning the original, beginning at the upper left-hand corner and continuing from left to right in equal sections with small overlaps. Each original is also photographed in one exposure and is included in reduced form at the back of the book.

Photographs included in the original manuscript have been reproduced xerographically in this copy. Higher quality $6 "$ " 9 9" black and white photographic prints are available for any photographs or illustrations appearing in this copy for an additional charge. Contact UMI directly to order.

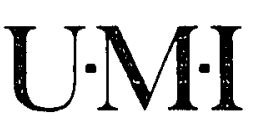

University Microfilms Internatıonal

A Bell \& Howell information Company

300 North Zeeb Road. Ann Arbor. MI 48106-1346 USA

313:761-4700 800:521-0600 
. 
Order Number 1350124

Feeding habits of the midwater polychaete, Poeobius meseres (Heath, 1930) in Monterey Bay, California

Uttal-Cooke, Lisa, M.S.

San Jose State University, 1992 

FEEDING HABITS OF THE MIDWATER POLYCHAETE, POEOBIUS MESERES (HEATH, 1930) IN MONTEREY BAY, CALIFORNIA

\author{
A Thesis \\ Presented to \\ The Faculty of Moss Landing Marine Laboratories \\ San Jose State University
}

\author{
In Partial Fulfillment \\ of the Requirements for the Degree \\ Master of Science
}

By

Lisa Uttal-Cooke

August, 1992 
APPROVED FOR MOSS $L A N D Y N G$ MARINE LABORATORIES

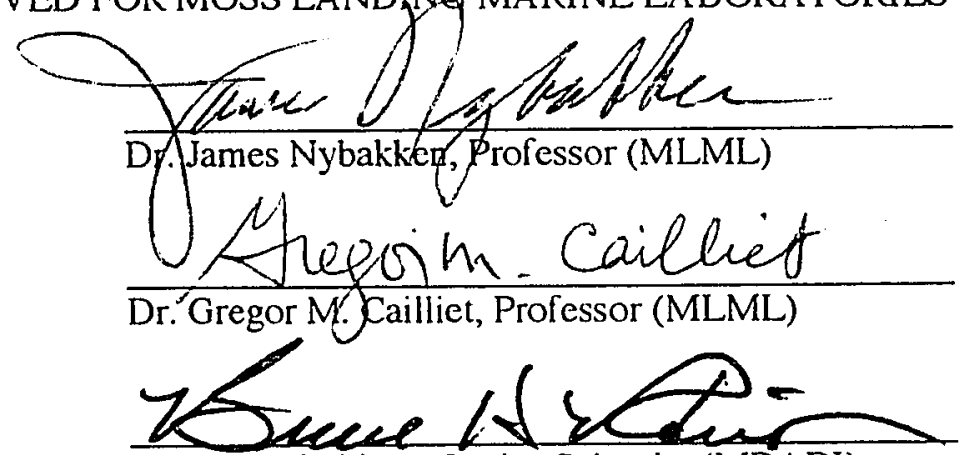

Dr. Bruce Robison, Senior Scientist (MBARI)

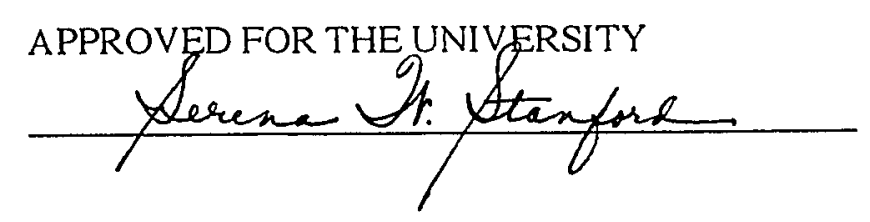




\section{ABSTRACT \\ FEEDING HABITS OF THE MIDWATER POLYCHAETE, POEOBIUS MESERES (HEATH, 1930) IN MONTEREY BAY, CALIFORNIA \\ by Lisa Uttal Cooke}

This study presents the first quantitative and temporal feeding study of a gelatinous midwater organism. With the Monterey Bay Aquarium Research Institute's remotely operated vehicle (ROV), VENTANA, regular collections of Poeobius meseres over a one year period have yielded both qualitative and quantitative results of feeding morphology and stomach contents. In situ observations suggest that $P$. meseres feeds in two possible ways: 1) it may produce mucus which collects particles from the water column for consumption; and 2) it may feed on detrital material in the water column with its ciliated tentacles. Results from stomach content analysis show conclusively that $P$. meseres is primarily coprophagic with a diet dominated by fecal pellets from euphausiids and copepods. Although fecal pellets were the most important food item volumetrically, $P$. meseres also consumed large numbers of diatoms and small numbers of dinoflagellates, radiolarians, foraminiferans, chrysophytes and eggs. The diet of $P$ : meseres appears to reflect primary productivity in the surface waters with different food items abundant in the diet at different times of the year. Pennate diatoms were most abundant in the diet during the fall; centric diatoms were most abundant during the summer, and fecal pellets during the winter. The composition of $P$. meseres diet suggests that these and other midwater gelatinous organisms may have a significant role in the remineralization of particles as they sink from the surface to the deep. 


\section{ACKNOWLEDGMENTS}

I give my thanks to all those at Moss Landing Marine Laboratories who have been there during this unique educational experience. Special thanks to the faculty and staff, especially Sheila Baldridge and Gail Johnston. To my friends, Kim Burdett, Jane Allen King and Ann Summers for their encouragement and help during my thesis.

Granting and funding for this study was provided in part by the Earl and Ethel Meyers Foundation and the David and Lucille Packard Foundation. The University of California, Santa Cruz EM facility was gracious enough to allow me to use their facility on numerous occasions.

To Jeff and Cass Schrock at Monterey Bay Kayaks, I owe so much for their support through my graduate work and for providing a terrific diversion during my research.

To all the Monterey Bay Aquarium Research Institute folks who contributed to my research in so many ways. The crew of the R/V Pt. Lobos, Kim Reisenbichler, Jenny Paduan, Marilyn Yuen, Annette Gough, Steve Lowder, Francisco Chavez, Cindy Pilskaln, Lynn Lewis and Mary Silver, your support was greatly appreciated. I would especially like to extend my appreciation to Kurt Buck at MBARI, who has taught me the art of scanning electron and epifluorescence microscopy. He gave me the inspiration to forge forward during all those long hours on the scope.

To my advisors at Moss Landing Marine Laboratories, Dr. James Nybakken and Dr. Greg Cailliet, for their inspiration, support, expertise and feedback. They provided me with a balanced learning experience to becoming a research scientist. To my advisor, Dr. Bruce Robison at MBARI, I owe so much for giving me the opportunity to conduct deep-sea research. Many thanks for his constant support.

Finally, to my family, Dr. and Mrs. William R. Uttal and my husband, Tim who continue to provide support and inspiration in all of my endeavors. 


\section{TABLE OF CONTENTS}

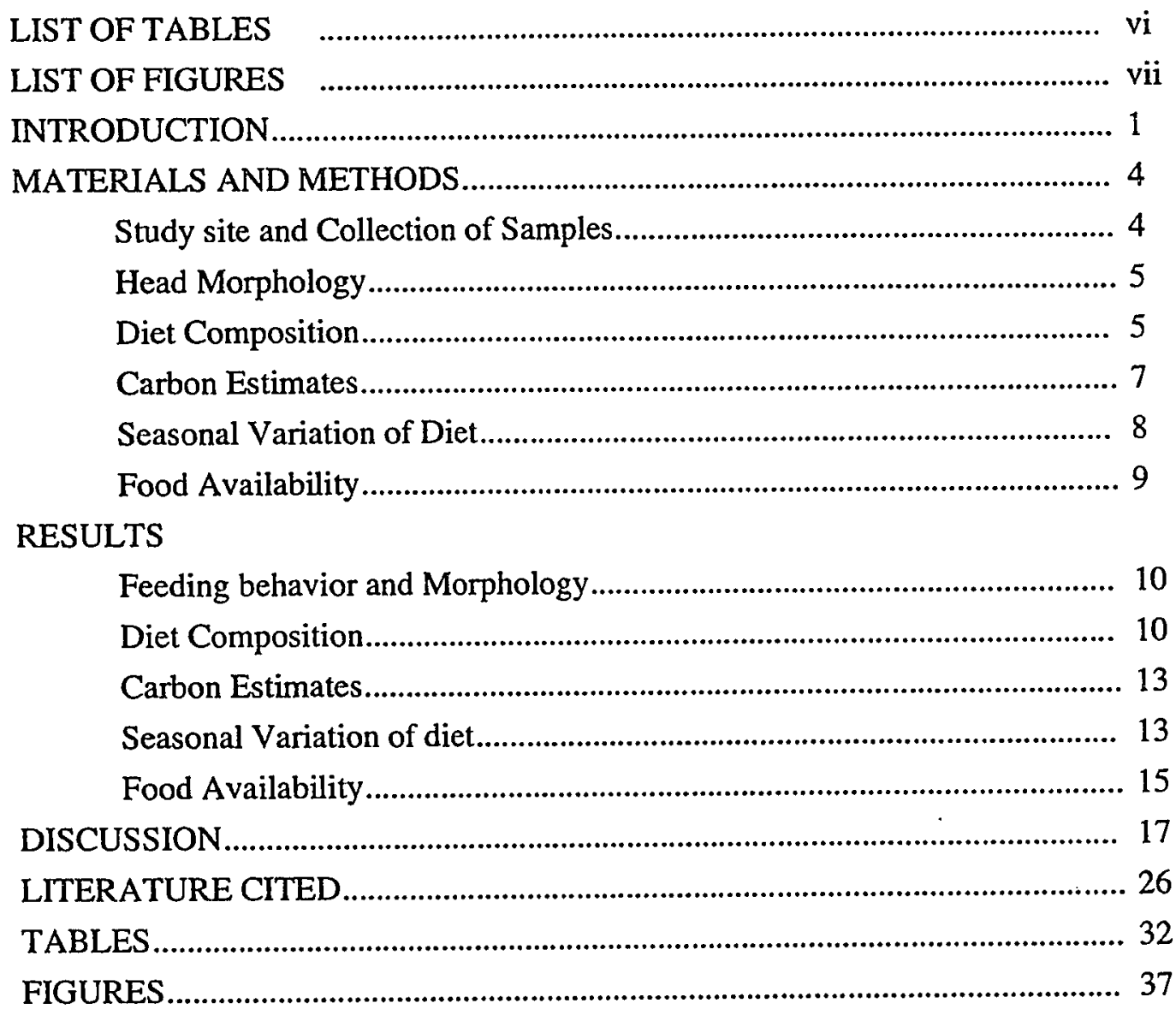




\section{LIST OF TABLES}

Table

1. Relationships used to calculate the volume and carbon content of food groups in the stomachs of $P$. meseres.

2. Food items found in the stomachs of $P$. meseres.

3. Values for total composition of major food groups in the stomachs of $P$.meseres. (Mean \%number + mean \%volume) X (\%frequency of occurrence) $=$ Index of relative importance (IRI)(Pinkas et al., 1971).

4. Values for total composition of major food groups in the stomachs of $P$. meseres over three oceanographic seasons.

5. Percent Similarity Index (PSI) comparisons of the number of food items in the stomach of $P$. meseres with the number of available food items per liter in water samples collected at the same time and place. 


\section{LIST OF FIGURES}

\section{Figure}

\section{Poeobius meseres}

2. Study site.

3. Scanning electron micrographs of feeding tentacles of $P$. meseres.

4. Adequacy of sampling of stomachs of $P$. meseres over a one-year period.

5. Composition of major food groups in \%number, \%volume and \%frequency of occurrence.

6. Scanning electron micrographs of fecal pellets in the stomach contents of $P$. meseres.

7. Scanning electron micrographs of centric diatoms in the stomach contents of $P$. meseres.

8. Scanning electron micrographs of pennate diatoms in the stomach contents of $P$. meseres.

9. Scanning electron micrographs of less abundant food items in the stomachs of $P$. meseres.

10. Comparison of the relative \%volume of nutritious and non-nutritious food groups in the stomachs of $P$. meseres. Percent volume of nutritious food items in the stomachs.

11. Adequacy of sampling for three oceanographic seasons.

12. Comparison of the composition of major food groups in the stomachs of $P$. meseres over three oceanographic seasons.

13. Comparison of the relative abundance of the three most common food groups in the stomachs of $P$.meseres.

14. Stomach of $P$. meseres packed from mouth to anus with fecal pellets. Euphausiid fecal pellets from the stomach contents of $P$. meseres. 


\section{INTRODUCTION}

Gelatinous zooplankton include a heterogeneous assemblage of soft-bodied organisms which are diverse in the world's pelagic marine ecosystems. These organisms are abundant in the epipelagic (Seki, 1973; Hirota; 1974; Hamner et al., 1975; Harbison et al., 1978; Deibel, 1980; Biggs et al.; 1981; Purcell, 1981a) and the mesopelagic zones of the ocean (Barham, 1957; Rogers et al, 1978). Past studies suggest that gelatinous zooplankton are significant consumers and have a large impact on the trophic structure of marine ecosystems (Alldredge, 1984; Michaels and Silver, 1988). Quantitative analyses of diet composition have been made for several epipelagic groups such as scyphozoans (Larson, 1978), ctenophores (Hirota, 1974; Anderson, 1974), siphonophores (Biggs, 1976;

Purcell,1981 ,a,b, 1982; Purcell and Kremer, 1984), heteropods (Seapy,1980), appendicularians (Diebel, 1980; Alldredge, 1981; Alldredge and Madin, 1982) and salps (Madin, 1974). Comparatively little information is available regarding the types and quantities of food consumed by mesopelagic gelatinous organisms.

Study of these fragile organisms has been hampered due to difficulties associated with collecting and/or observing at depth. Whereas pelagic organisms studied at one place and time may yield important infomation, returning to that same habitat time after time to study populations is impossible because the water column is three-dimensional and continuously moving. Additionally, traditional sampling with midwater trawls has underestimated the actual importance of many gelatinous organisms and does not successfully sample what are known to be large populations. Gelatinous organisms collected with trawls usually come to the surface as indistinguishable pieces of jelly, and little is known about the exact depth or location from which they were collected. With the recent advent of remotely operated vehicles (ROVs) and manned submersibles, gelatinous organisms can now be sampled without many of the problems of trawling. 
Collections from submersibles and ROVs in situ with appropriate sampling devices can yield intact organisms for which the depth, location and time of capture is known.

Among these ubiquitous groups of mesopelagic, gelatinous organisms is the unusual polychaete, Poeobius meseres Heath (1930). Poeobius meseres is distinguished from a typical polychaete in that it lacks external segments, setae and parapodia. Ranging up to $27 \mathrm{~mm}$ in length, the transparent body has a visible digestive tract, and the body is separated by septa into three coelomic spaces (Fig. 1). As a result of these and other unusual morphological and physiological characteristics, $P$. meseres ' taxonomic position remains uncertain. It has been placed in the phyla Echiura (Grasse, 1959) and the Annelida (Pickford, 1947; Hartman, 1955; Berkeley and Berkeley, 1960; Dales, 1963), as well as somewhere between these two (Heath, 1930; Fisher, 1946). The most recent classification considers $P$. meseres to be most closely related to the Flabellegerid polychaetes because the tentacles are retractable and they have chlorocruorin as one of their blood pigments . Currently, P. meseres is placed in its own family, the Poeobiidae (Hartman, 1955).

Poeobius meseres has a discrete vertical distribution in the water column. Individuals are distributed throughout the continental borderlands of the North Pacific Ocean with greatest abundance occurring from 150-300 $\mathrm{m}$ in the western Pacific and from 300-1300 $\mathrm{m}$ in the eastern Pacific (Hartman, 1955; McGowan, 1960). In a brief reference, Barnes et al. (1976) estimated a density of 3 P. meseres per $100 \mathrm{~m}^{3}$ from submersible dives off southern California. In the Monterey submarine canyon in Monterey Bay, California, $P$. meseres has been observed frequently from dives with the remotely operated vehicle, VENTANA, year-round between depths of 260-950 m. Despite apparent high abundances, the ecological importance of $P$. meseres in the midwater is not yet known. 
Recent studies suggest that midwater organisms are important in mediating the overall flux of particles from the surface waters to the deep (Alldredge and Silver, 1988; Michaels and Silver, 1988). Although physical processes such as turbulence and mixing contribute to the degradation of materials in the water column, it seems likely that grazers are important in the remineralization of materials (Alldredge, et al., 1990). The estimated order of magnitude of reduction in the abundance of detrital material below the epipelagic zone (Martin, et al., 1987) suggests that the role of consumption should be quantified. Organisms consuming detrital material may represent a significant mechanism by which material is broken down in the water column. However, no quantitative information exists regarding the importance of consumption by midwater gelatinous organisms.

This study examines feeding habits of $P$. meseres in an effort to understand its ecological role as a gelatinous consumer in Monterey Bay. The specific goals of this study were to: 1) describe the feeding apparatus to gain insight into how $P$. meseres feeds; 2) qualitatively and quantitatively determine the composition of food items in the stomachs of $P$. meseres throughout one year including three seasons; 3 ) examine the diet of $P$.meseres with regard to food availability; and 4) to evaluate the ecological implications of feeding by $P$. meseres in midwater. 


\section{MATERIALS AND METHODS}

\section{Study Site and Collection of Samples}

This study was conducted in the deep waters of the submarine canyon of Monterey Bay, California. This study was part of scientific cruises by Dr. Bruce Robison at the Monterey Bay Aquarium Research Institute (M.B.A.R.I.) and therefore, all dives were conducted at his study sites. The study area was situated approximately 7 miles northwest of Pt. Pinos ( $36^{\circ} 42^{\prime} \mathrm{N}, 122^{\circ} 02^{\prime} \mathrm{W}$ )(Figure 2), and lies over the canyon in $1640 \mathrm{~m}$ of water. One of two midwater stations within one mile of each other were visited over a one year period for a total of 27 ROV dives made from the R/V PT. LOBOS.

In situ observations and collections of $P$. meseres were conducted with the Monterey Bay Aquarium Research Institute's Hysub ROV, VENTANA, made by International Submarine Engineering. From October, 1990 to November, 1991, $70 P$. meseres were collected into one of five 2-liter cannisters with a variable speed suction sampler mounted on the ROV. All collections were between depths of 260-480 m, which is the uppermost vertical distribution of $P$. meseres. Simultaneous real-time observations of $P$. meseres with a high resolution Sony DXC 3000 video camera mounted on the ROV, were conducted during all collections. Upon retrieval of the ROV, specimens were fixed in $5 \%$ formalin for gut content analysis and $2 \%$ glutaraldehyde for scanning electron microscopy.

To study the availablity of potential food in the water column, samples of seawater and $P$. meseres were collected with the ROV at the same time and place. Seawater samples were collected in a $200 \mathrm{ml}$ GO FLO water bottle mounted within the tool sled of the ROV. The tripping mechanism of the bottle was activated hydraulically after the collection of a $P$. meseres into the suction sampler. It was only possible to collect one water sample per dive due to the configuration of equipment on the ROV and 
the type of tripping mechanism employed. Upon retrieval, all water samples were shaken in case of settling and preserved in $5 \%$ formalin .

\section{Head Morphology}

Observations of head morphology were made on preserved specimens with a scanning electron microscope (SEM) to gain insight into the way $P$. meseres feeds. The heads with palps and cirri were carefully excised with a scapel at the beginning of the digestive tract, dehydrated in a graded ethanol series $(70 \%-100 \%)$, soaked in $100 \%$ ethanol, postfixed in osmium tetroxide, critical-point-dried in carbon dioxide, coated with gold and photomicrographed with an ISI \#WB-6 SEM. Entire visible surfaces of the cephalic region, including palps and cirri, were photographed.

\section{Diet Composition}

In filtered seawater, digestive tracts of preserved specimens of $P$. meseres were removed by teasing away the outer hypodermis and the inner epithelium. Stomach contents were placed into a settling chamber base, dispersed and stained with $0.2 \mathrm{ml}$ nuclear fluorochrome diamidinophenylindole (DAPD)(Gowing and Coale, 1989). All food items in the entire stomach were examined at $320 \mathrm{X}$ magnification, identified to the lowest taxon possible, tallied, and their length, width and/or thickness were measured with an occular micrometer on a Zeiss Axiovert 10 epifluorescence inverted phase contrast microscope. Since only two dimensions (length and width or length and thickness) of some of the diatoms and dinoflagellates were visible under the microscope, assumptions about the third dimension were made based on values from Kovala et al. (1965): 1) Centric diatoms, thickness of valve $=0.5 \times$ length (diameter); 2) Pennate diatoms: width of valve $=$ thickness of valve; and 3) Dinoflagellates: $0.5 \mathrm{x}$ width $=$ thickness. If only fragments of food items were present, the dimensions were still 
measured so that estimates of those kinds of food present could be made. All food items were assigned a shape (sphere, ellipsoid, cylinder or pennate) and converted to volumes using the appropriate geometric formulae (Table 1).

Light microscope observations of diatoms with one valve intact were often difficult to differentiate from those with both valves intact; therefore, most cells were considered whole in the volume calculations. Although both length and diameter of the pellets were recorded, fecal pellet types were based on pellet diameters because the diameter is related to the size of the producer and because cylindrical pellets easily break into pieces. Minipellets were differentiated from fecal pellets by their elliptical shape and small size $(<50 \mu \mathrm{m})$ (Gowing and Silver, 1985). Only food items larger than $5 \mu \mathrm{m}$ were counted; therefore, bacteria were not considered in this study.

Individual food types were grouped into 12 major food categories for analysis (Table 2 , in bold). The percent number and percent volume of each food group were averaged for all samples to determine overall percentages. Frequency of occurrence of each food group was calculated by taking the percentage of stomachs in which an item occurred. Diet was represented by the Pinkas et al. (1971) Index of Relative Importance (IRI), in which each food group's importance is a combination of the numerical importance $(\% \mathrm{~N})$, volumetric importance $(\% \mathrm{~V})$, and frequency of occurrence $(\% \mathrm{FO})$ according to the equation; $\mathrm{IRI}=(\% \mathrm{~V}+\% \mathrm{~N})(\% \mathrm{FO})$, which was represented as rectangles in three-way graphs with $\% \mathrm{~N}, \% \mathrm{~V}$ on the $y$-axis and $\% \mathrm{FO}$ on the $\mathrm{x}$-axis. The IRI value is actually the area of the rectangle and is a measure of the relative importance of each food item compared to the others. The IRI can range from zero (food item not found in diet) to 20,000 (when all three variables are $100 \%$ or a monodiet) (Cailliet and Ebeling, 1990). Volume was the most meaningful measure of a food group's contribution to the diet. Percent number and percent frequency of occurrence overestimated the importance of small prey, especially pennate and centric diatoms. 
Scanning electron microscopy of stomach contents was conducted to further characterize the food items ingested by $P$. meseres. Stomach contents of specimens fixed in $5 \%$ formalin were placed in filtered seawater and drawn onto $0.2 \mu$ Nuclepore membrane filters, washed with distilled water and air dried. Filters were mounted onto stubs with double sided tape, were sputter coated with gold palladium and photomicrographed for identification.

Adequacy of sample size for food items was tested by plotting the cumulative number of all food items in Table 2 against the number of stomachs analyzed. The counts for individual stomachs were randomly accumulated one at a time, until the cumulative number of food items and species increased to the total food items observed in the stomachs (Hurturbia,1972). This was done 10 times and the mean trophic diversity, with its standard error, was calculated.

\section{Nutrition}

Phytoplankton and microzooplankton with intact protoplasmic and nuclear material stained bright blue with DAPI and were categorized as "nutritious," along with fecal pellets, minipellets and eggs. Empty frustules of phytoplankton, tests and shells of microzooplankton, crustacean exoskeletons and moults were categorized as "nonnutritious." Volumes for both nutritious and non-nutritious food items were calculated (as described for diet composition) and compared. Carbon content for nutritional food categories in foreguts and hindguts were estimated using appropriate volume to carbon relationships from the literature (Table 1).

\section{Seasonal Variation of Diet}

To investigate diet changes over the year, stomach contents of $P$. meseres were analyzed and processed in a manner similar to that described for total composition and 
were compared among three oceanographic seasons. Identification of seasons was based on temperature data from bottle casts in Monterey Bay in 1991 (Rosenfeld, MBARI, unpubl. data) and compared with a 6-year study by Bolin and Abbott (1963) in Monterey Bay. Seasons were defined as: 1) The Davidson period (November-February), characterized by strong southerly winds and uniform temperatures; 2) the Upwelling period (March-August), characterized by northwesterly winds driving surface water offshore, with deep, cold, nutrient-rich water upwelling to replace it; and 3) the Oceanic period (September-October), characterized by calm weather and high thermal stratification. A total of $19 P$. meseres stomachs was analyzed during the Davidson period; 33 stomachs were analyzed during the Upwelling period and 10 stomachs were analyzed during the Oceanic period.

Adequacy of sampling was calculated similar to total composition (see above) for the total number of stomachs sampled during three oceanographic seasons; however, because of the small sample size during the Oceanic and Davidson periods, food types were grouped into the 12 major food categories (Table 2 , in bold).

The IRI for each season was determined and the Kendall-tau rank correlation test (Sokal and Rohlf, 1969) was used to test for similarity between \% N and \% V of food groups between three seasons. Rank correlation was used because of the very large sample size required for parametric tests and to avoid the assumptions of normality.

The differences in abundance of the three dominant food groups in the stomachs of $P$. meseres were estimated on a bimonthly basis because there was no significant difference among the food types between seasons. The mean number of individual food items was calculated for food items such as fecal material (including minipellets), pennate diatoms (Nitzschia spp., unidentified pennates) and centric diatoms (Skeletonema spp., Chaetoceros spp., Rhizosolenia spp., Thallasiosira spp., and unidentified centrics) and compared in area graphs. 
Food Availability

Fifty milliliters of preserved seawater were subsampled from water collected at the same time as $P$. meseres, allowed to settle for a minimum of 24 hours and stained with DAPI for microscope identification and counts of available food particles. Six samples were collected: on July 17 and 22, September 30, October 4, 24 and November 22,1991 . As with stomach content analysis, all identifiable organisms and detrital material were counted in a settling chamber at $320 \mathrm{X}$ magnification. The concentrations of both "nutritious" and "non-nutritious" available food in the $50 \mathrm{ml}$ subsamples were extrapolated to one liter. Comparisons among all six samples were made with Percent Similarity Indices (PSI)(Sanders, 1960). 


\section{RESULTS}

\section{Feeding Behavior and Morphology}

Remotely operated vehicle observations indicate that $P$. meseres collected its food in two possible ways. Poeobius meseres was observed hanging neutrally buoyant in the water column, attached to what appeared to be mucus spread out above the body. The mucus was always connected to the head region of the worm as "strings" or a "net" and was densely aggregated with small particles. The composition of the particles attached to the mucus was difficult to determine because water-turbulence from the ROV destroyed it when the vehicle came too close. Although it is not known if $P$.meseres produces mucus in the water column, 480 video observations of $P$.meseres showed 70 worms associated with mucus, 10 worms associated with detrital material and 400 not associated with any kind of mucus or detrital material. Poeobius meseres was also observed frequently with its tentacles attached to large aggregates of detrital material or marine snow.

In the cephalic region of $P$.meseres, there is a pair of thick, longitudinally grooved palpi, 5-6 pairs of cirri in a transverse row, and a lip complex surrounding the mouth. Each palp has two types of ciliary structures, short cilia running along the groove and tufted cilia located along the lateral edges of the palp (Figure 3 a,c). Each cirrus has dense bands of cilia along the tip with diagonal bands of cilia encircling the entire length (Figure $3 \mathrm{~b}, \mathrm{~d}$ ). The surface area without ciliation was convoluted. SEM observations did not reveal any pores. Pores would be expected to constitute glandular areas from which mucus is secreted.

\section{Diet Composition}

The mean cumulative number of food items plotted against the pooled number of stomachs indicated the number of $P$. meseres sampled was adequate to sufficiently describe the total composition of the diet. The curve leveled off at approximately 25 of 
the 62 stomachs sampled (Figure 4). Standard error approached zero in all ten randomizations of the 62 stomachs.

Examination of 62 stomachs revealed that $P$. meseres fed on fecal pellets, phytoplankton and microzooplankton (Table 2). The diet was dominated by fecal pellets, pennate diatoms, centric diatoms and crustacean exoskeletons using all three measures of importance. The IRI values, represented by the areas of the rectangles in Figure 4, for fecal pellets (8694), pennate (3960) and centric diatoms (3306) were significantly larger than for any of the other food items (Table 3). Numerically, P. meseres ingested mostly pennate diatoms, fecal pellets and centric diatoms, while volumetrically the bulk of the diet was comprised of fecal pellets, crustacean exoskeletons and centric diatoms (Table 3). Fecal pellets, and centric and pennate diatoms occurred in more than $90 \%$ of the stomachs sampled while minipellets, tintinnids and crustacean exoskeletons occurred in $72 \%, 79 \%$, and $64 \%$ of the stomachs, respectively. Dinoflagellates occurred in $45 \%$ of the stomachs, with radiolarians, foraminiferans, moults, eggs, and chrysophytes occurring in less than $25 \%$ of the stomachs sampled.

Fecal material from zooplankton made the most important contribution to the diet of $P$.meseres. Fecal pellets from euphausiids, copepods and larvaceans occasionally contributed an average $58 \%$ of the total diet numerically and an average of $30 \%$ of the diet volumetrically. The majority of fecal pellets observed were cylindrical in shape and were characteristic of euphausiids and copepods (Martens, 1978). Euphausiid fecal pellets were large (up to $200 \mu \mathrm{m}$ in diameter), with frayed ends. Frequently, antennae and appendages from crustaceans protruded out of the broken ends of pellets. Copepod fecal pellets were small (up to $50 \mu \mathrm{m}$ diameter) with pinched off ends and were much less prevalent than large euphausiid fecal pellets (Figure 6b). Minipellets were also present in the diet, but did not contribute substantially in number $(7 \%)$ or volume $(2 \%)$ (Figure 6 c,d). 
Fecal pellets in the hindgut of $P$. meseres appeared watery and remained intact when stomach contents were egested from animals observed in a petri dish.

Observations using scanning electron microscopy revealed that fecal pellets and minipellets contained numerous diatom fragments as well as complete frustules (Figure 6). Rare occurrences of radiolarian and foraminiferan fragments and shells were also observed in fecal pellets.

Intact diatom frustules and chains not associated with fecal pellets made the second most important contribution to the diet of P.meseres. Centric diatoms with cell diameters between $9-800 \mu \mathrm{m}$ were conspicuous contributors to the diet, represented primarily by Skeletonema spp., Coscinodiscus spp., Rhizoselenia spp., Thalassiosira spp. and Chaetoceros spp. (Figure 7). They contributed an average $25 \%$ of the total diet numerically and an average $16 \%$ of the diet volumetrically. Centric diatom resting spores were also occasionally observed in the samples (Figure 7c). Pennate diatoms with valve lengths of 15-260 $\mu \mathrm{m}$ were predominantly a single species of Nitzschia, or possibly Pseudonitzschia australis, and various species of Navicula, Pleurosigma, Sururiella and Grammatophora (Figure 8). Pennate diatoms were very important numerically, contributing $32 \%$ to the total diet. However, they were rather insignificant volumetrically $(2.5 \%)$ (Figure 5).

Tests of dinoflagellates and radiolarians, skeletons of chrysophytes, lorica of tintinnids and appendages and antennae exoskeletons from crustaceans contributed less than $10 \%$ of the total number and volume to the remaining part of the diet of P.meseres (Figure 9). Whole crustacean moults and eggs from crustacean zooplankton were rare, present in only 5 of the 62 stomachs sampled and contributing less than $1 \%$ of the total diet.

Additional very small size cells $(<5 \mu \mathrm{m})$ were observed in the stomach contents with the light microscope. These may have been the grey bodies or "olive-green bodies" 
described by Silver and Alldredge (1981). As they occurred much less frequently and were difficult to identify, they were not included in the counts of food types. Small amounts of unidentifiable detrital material also occurred, but were not considered in the diet analysis.

\section{Carbon estimates}

The degradation of the internal protoplast of DAPI-stained phytoplankton and microzooplankton was observed with the light microscope. In general, empty silicious valves remained whole and were easily distinguished from intact frustules, tests and shells of phytoplankton and microzooplankton with protoplasm. Nutritious food groups in the diet of $P$.meseres were primarily fecal pellets, minipellets and diatoms, contributing an average percent volume of $75 \%, 17 \%$, and $7 \%$, respectively (Figure 10a). Dinoflagellates, radiolarians and eggs contributed less than $1 \%$ of the total volume of nutritious food items in the diet. In contrast, non-nutritious pennate diatoms and centric diatoms accounted for an average $58 \%$ and $41 \%$ of the volume while crustacean exoskeletons, tintinnids, dinoflagellates, chrysophytes, radiolarians and foraminiferans contributed less than $10 \%$ of the total volume in the diet.

Fecal pellets contributed an average of $97 \%$ of the carbon to the diet of $P$. meseres (Figure 10c). Comparatively, minipellets and pennate diatoms contributed minute quantities ( $2 \%$ and $1 \%$, respectively) to the overall nutrition of the diet.

\section{Seasonal Variability}

Adequacy of sampling was calculated for three oceanographic seasons for 12 major food groups. During the Davidson period $(n=19)$, the mean cumulative number of food categories leveled off at 9 stomachs (Figure 11a) and during the Upwelling period 
$(\mathrm{n}=33$ )(Figure $11 \mathrm{~b}$ ), the mean cumulative number of food categories leveled off at 11 , indicating adequate sampling . During the Oceanic period $(n=10)$ (Figure 11c), the mean cumulative number of food types did not level off, due to the small sample size and four rare food groups (chrysophytes, moults, eggs and radiolarians) present in only a few stomachs. Because they were rare and the sample size was small, they did not occur often enough to allow the curve to level off.

Poeobius meseres ate the same general kinds of food over three seasons, with its diet dominated by fecal pellets, pennate diatoms, centric diatoms and crustacean exoskeletons. Ranks of food items for $\% \mathrm{~N}$ and $\% \mathrm{~V}$ were significantly correlated between all three seasons (Kendall-tau, $\mathrm{p}<<.01$ ); however, different types of foods dominated the diet during different seasons (Figure 12). Fecal pellets in the stomachs of $P$. meseres ranked first in dietary importance during the Davidson (IRI=9960) and the Upwelling periods ( $I R I=8987)$, but ranked second in dietary importance during the Oceanic period $(\mathrm{IRI}=5359)$ (Table 4). Pennate diatoms were consistently important in the diet throughout all three seasons ranking first in the diet during the Oceanic period ( $I R I=8276)$, and ranking second and fourth during the Davidson (IRI=4114) and the Upwelling periods (IRI=1612). Centric diatoms ranked second in the diet during the Upwelling period ( $\mathrm{RI}=5359$ ), contributing substantially less to the diet during the two other seasons, ranking third during both the Davidson period (IRI=1575) and the Oceanic period $(\mathrm{IRI}=3638)$.

Crustacean exoskeletons were most important in the diet during the Upwelling period (IRI=2024), but were significantly less important during the other two seasons. Minipellets, tintinnids, dinoflagellates, radiolarians, moults, eggs and chrysophytes were not important and did not contribute much to the diet of $P$. meseres. The combined IRI values were less than 1000 in all three seasons. 
Although the composition of food groups was not significantly different between the three seasons, the abundance of major food species and types varied from month to month (Figure 13). Throughout the year, P. meseres ingested high numbers of pennate diatoms. The major species which dominated the stomachs was Pseudonitzschia australis, contributing $88 \%$ numerically during September and October. Several other genera, including Navicula, Pleurosigma, Pseudoenotia, Amphora, Sururiella, Grammatophora and unidentified pennates were present in less than $9 \%$ of the stomachs. A gradual decline of $P$. australis spp. from January to March was marked by an increased number of fecal pellets in the stomachs of $P$. meseres (Figure 13b). In March and April, fecal pellets made up 59\% of total stomach contents, up from $21 \%$ in January and February. Entire stomachs were packed from mouth to anus with euphausiid fecal pellets (Figure $14 \mathrm{a}, \mathrm{b}$ ). In May and June, fecal pellet abundance dropped to $37 \%$ of the total stomach contents, dropping even lower to $4 \%$ in September and October until November when there was an increase to $19 \%$. Minipellets contributed a small percentage of the fecal pellet contribution to the diet throughout the year with a peak abundance of $13 \%$ during January and February.

Centric diatoms were a conspicuous component of $P$.meseres' diet throughout the year (Figure 13c). Peak abundances of Rhizosolenia spp. (22\%), Chaetoceros spp. (11\%) and unidentified centrics (16\%) occurred in July and August, and abundances dropped off to less than 3\% during September and August. Skeletonema spp. (14\%) was most abundant during March and April. Thalassiosira spp. was consistently present in the diet in low numbers $(<3 \%$ throughout the year).

\section{Food Availability}

With the exception of ciliates, radiolarians, chrysophytes and moults that occurred rarely, the stomach contents of individual $P$. meseres and the water column samples 
contained the same types of organisms and detrital material. These included fecal pellets, minipellets, crustacean exoskeletons, tintinnids, centric and pennate diatoms and dinoflagellates.

Examination by light microscopy of the water column samples revealed high numbers of chain diatoms. In comparison, examinations of the stomach contents contained low numbers of chain diatoms. As noted in diet composition analyses, fecal pellets in the stomachs were often broken into pieces with frayed ends. In contrast, fecal pellets were generally intact in the water samples.

Comparison of the stomach contents to water column samples with Percent Similarity Indices (PSI) indicated that samples $\# 1$ and $\# 2$ collected in the summer were similar in composition among each other while samples \#3, \#4 and \#6 collected in the fall were similar in composition among each other (Table 5). Stomach \#5 and water sample \#5 were not similar to each other or any of the other samples collected. 


\section{DISCUSSION}

\section{Eeeding Behavior and Morphology}

ROV observations suggest $P$. meseres is a suspension feeder, passively collecting detrital material in the water column. Poeobius meseres appears to feed with a fine, delicate structure of mucus that originates from the anterior end of its body. The small particles of marine snow collected on the surface of the "net" made it appear more dense than the surrounding waters. In the benthic and pelagic environments, mucous webs are an optimal foraging strategy for maximizing food collection (Hamner et al. 1975; Jorgensen, 1981). Many benthic polychaetes and the pelagic larval polychaete, Poecilochaetus sp. are known to feed with mucous nets. Poecilochaetus sp. secretes a three-dimensional network of fine strands to collect particles for ingestion. Secretion of a mucous web for food collection is also known in many pelagic organisms such as pteropods (Gilmer, 1972), appendicularians (Alldredge, 1977, Deibel, 1986) and salps (Madin, 1974). These studies suggest that feeding with an external mucous web is a fundamental adaptation enabling gelatinous organisms to exploit an abundant organic resource.

Although the production of the mucous by $P$. meseres was not observed, Robbins (1965) suggested that $P$. meseres traps particles with mucus secreted from glandular cells on the palps. It is possible that $P$. meseres could produce a net from these same cells. Deposit feeding polychaetes are known to secrete mucus from their tentacles to collect detrital material (Barnes, 1980). Chaetopterus sp. and Nereis sp. possess head structures analogous to tentacles which extend out over the substrate, adhering to particles with mucous secretions (Jorgensen, 1966).

In addition to the hypothesis that $P$. meseres collects food with mucus, it may also collect food from the water column by grasping sinking detrital material with its tentacles. Poeobius meseres was often associated with detrital material that appeared to 
be large aggregates of marine snow. Marine snow is a likely source of food because particles are known to be three times more concentrated on it than in the surrounding waters, providing a concentrated food source (Alldredge and Silver, 1988). Small larvacean houses and the carcasses of dead animals sinking through the water column while aggregating material, may also provide a source of food to $P$. meseres.

The scanning electron micrographs of the tentacles of $P$. meseres suggest that the cilia have an important role in handling food. The five pairs of heavily ciliated cirri probably transport particles of food to the palps as well as carrying food directly to the mouth. Particles of food on the palps may be transported to the mouth via the ciliary groove. Benthic deposit feeding polychaetes with grooved palps are known to handle small food particles differently from large particles (Dales, 1955). Small food particles are transported along the groove primarily by ciliary action. Large particles are transported along the groove by both ciliary action and muscular squeezing. Dales (1955) proposed that the groove of a tentacle can be partly opened or closed to form a tube, facilitating the transport of large food items. Food items too large for transporting along the groove are attached to the densely ciliated cirri and moved directly to the mouth.

The role of the cilia arranged in tufts on the palps of $P$. meseres is unknown; they may have a chemosensory or mechanosensory function (Figure $3 \mathrm{a}, \mathrm{c}$ ). The tufts do not appear large enough to actually pick up and handle food. Morphologically similar structures have been described on the tentacles of the polychaete, Eupolymnia nebulosa (Gremare, 1988) and Owenia sp. (J. Nuremburg, Smithsonian, pers. comm.) and are thought to sense particle densities.

In contrast to most pelagic polychaetes which are active carnivores, seeking fast swimming zooplankton prey (Dales and Peter, 1972), P. meseres is a passive detritivore. This mode of feeding is typical of benthic terebellids and spionids (Bames, 1980). These 
findings support the hypothesis that $P$. meseres evolved from a benthic polychaete Robbins (1965). Poeobius meseres is thought to be most related to benthic flabellegerid polychaetes which have chlorocruorin blood and retractable tentacles (Hartman, 1955).

\section{Diet Composition}

The diet composition data are consistent with the hypothesis that $P$. meseres ingests aggregates of marine snow. Fecal pellets, diatom frustules, crustacean exoskeletons, bacteria and microzooplankton were the dominant kinds of organisms and detrital material found on epipelagic and bathypelagic aggregates of marine snow (Silver et al., 1978; Silver and Alldredge, 1981). These studies suggested that marine snow makes food items such as fecal pellets and diatoms more readily available for consumption by large zooplankton.

The most important food items volumetrically in the stomachs of $P$. meseres were fecal pellets that originated from euphausiids, copepods and other metazoans. Poeobius meseres consumed primarily large cylindrical fecal pellets ranging up to $200 \mu \mathrm{m}$ in diameter. Small fecal pellets from zooplankton copepods ( $<30 \mu \mathrm{m}$ in diameter) were less abundant than large fecal pellets. Poeobius meseres may have ingested large fecal pellets more frequently because they were more available in deep waters. Very small fecal pellets are thought to be most abundant in surface waters, becoming degraded or consumed before they can sink to deep depths (Paffenhofer and Knowles, 1979; Turner and Ferrante, 1979). In contrast, large, robust fecal pellets are thought to sink quickly before becoming deteriorated and therefore make it to deeper depths (Fowler and Small, 1972; Honjo and Roman, 1978; Paffenhofer and Knowles, 1979; Small et al., 1979).

Scanning electron microscope and light microscope observations indicate there are two types of fecal pellets ingested by $P$. meseres: one originating from herbivorous zooplankton and another originating from omnivorous zooplankton. Fecal pellets 
ingested by $P$. meseres contained well digested, triterated fragments of phytoplankton (Figure $4 \mathrm{a}, \mathrm{b}, \mathrm{c}$ ) as well as whole, intact cells of phytoplankton. The presence of diatom fragments and frustules is characteristic of fecal pellets from herbivores, including copepods (Turner, 1986; Turner, 1991) and euphausiids (Ikeda, 1984). Large fecal pellets ingested by $P$. meseres also contained crustacean antennae and appendages. The presence of crustacean pieces is characteristic of fecal pellets from omnivores, including euphausiids which are able to feed on a wide variety of food, including copepods, crustacean larvae and other euphausiids (Ikeda, 1984). Martens (1978) described similar signs of carnivory in the Atlantic ocean euphausiid, Meganyctiphanes.norvegica.

Many crustacean species are thought to be coprophagic and to have an important role as consumers in the water column (Frankenberg and Smith, 1967; Paffenhofer and Strickland, 1970; Paffenhofer and Knowles, 1979; Bishop et al., 1986; Lampitt et al. 1990). However, the importance of coprophagy in the diet of gelatinous deep-sea organisms has not been quantified. Fecal pellets have been found in the stomachs of lobate ctenophores (G. Matsumoto, MBARI, pers. comm.) and of the giant larvacean, Bathochordaeus charon (Robison, MBARI, unpubl. data). Fecal pellets are a predominant component of flux in the upper layers of the water column dropping off significantly below $500 \mathrm{~m}$ (Pilskaln and Honjo, 1987). The results of the present study indicate that coprophagy by $P$. meseres may be important to understanding pelagic food web interactions.

In addition to fecal pellets, the abundance of individual, autotrophic, ultrastructurally intact phytoplankton was an important food source in the diet of $P$. meseres. Nitzschia spp., a chain-forming pennate diatom, was the dominant form. When centric diatoms were present in significant amounts in the diet, the main contibutors were the genera Rhizosolenia, Thallasiosira, Chaetoceros, and Skeletonema. There are two potential sources of these phytoplankton. First, diatoms in the surface waters may 
aggregate with other detrital material and sink through the water column as marine snow, and then are ingested by $P$.meseres. Silver and Alldredge (1981) have shown that ultrastructurally intact phytoplankton is present on marine snow in the bathypelagic. Second, phytoplankton ingested by herbivores and egested as fecal pellets may be transported to the deep sea where P.meseres feeds on them. SEM observations suggest that diatoms and microzooplankton ingested by $P$. meseres originated from marine snow rather than fecal pellets because they were ultrastructurally intact and not well-digested.

\section{Carbon Estimates}

Poeobius meseres satisfied its nutritional requirements largely by feeding on fecal pellets. Fecal pellets provided a large and useful energy source, contributing $98 \%$ of the carbon by weight to the diet. In contrast, many of the other food items ingested were non-nutritious and consisted of siliceous frustules, tests, shells and chitinous material. These contributed very little carbon to the diet due to their small volume and low seasonal abundance. Siliceous food items present in the diet of P. meseres showed little external degradation due to their resilient nature.

Consumption of detrital material by $P$. meseres may result in the recycling or remineralization of materials sinking from the surface to the deep. It is generally believed that the flux of particles from the surface is a source of food for deep sea organisms (Vinagradov, 1962; Harding, 1974); however, the fate of detrital material in the ocean is poorly understood. Below the euphotic zone, the flux of materials is reduced with increasing depth (Martin et al., 1987) with the greatest losses of organic carbon occurring in the upper mesopelagic zone (Suess, 1980). These losses have been attributed to biological degradation through consumption, decomposition by microorganisms or physical processes such as turbulence and mixing (Alldredge and Silver, 1988). Alldredge et al. (1990) postulated that biological disaggregation due to 
grazing is more important than physical processes to the reduction of material in the water column, and that consumption by gelatinous organisms has been ignored as an important factor in overall carbon flux quantification.

Although data for carbon content calculations (Table 1) of food items were based on fresh fecal pellets, many of the fecal pellets ingested by $P$. meseres contained material which was probably reingested and digested several times. Digestive state was very difficult to measure quantitatively. Fecal pellets remained intact in both the foregut and hindgut; however, those in the hindgut appeared laden with water. Therefore, actual volume to carbon relationships used in this study are probably an overestimate of the carbon amount ingested.

Poeobius meseres may not break down all of its food completely, but might derive some of its nutrition by digesting bacteria on the outer peritrophic membrane of fecal pellets. Copepods have been observed ingesting the peritrophic membrane and attached bacterial flora of their own fecal pellets (Lampitt et al. 1990). Pilskaln and Honjo (1987) have found several structurally intact fecal pellets lacking a pellicle in sediment traps at $500 \mathrm{~m}$ and suggested that this may be a result of grazing by zooplankton.

\section{Seasonal Variation in Diet}

The general patterns of nutrient coupling between the shallow layers and the deeper benthic habitats has been outlined (Theil, et al., 1989; Sancetta and Calvert, 1988), but a complete understanding of the link between the surface waters and midwater has not been accomplished. It is not known if deep sea gelatinous organisms experience dietary seasonal pulses. This study shows that the diet of $P$. meseres may be dependent on seasonal fluctuations in primary productivity in the surface waters and on activity by zooplankton that create fecal pellets. This indicates that $P$. meseres may be opportunistic 
and consume whatever is available in the water column. The pattern of large numbers of pennate diatoms in the fall followed by large numbers of euphausiid fecal pellets in the stomachs of $P$. meseres during March and April corresponds well with camera observations of bathyl sediments by Lampitt (1985) and Billett et al. (1983). Their research suggested that transport of algal flocs early in the growth season alternated with zooplankton fecal pellet transport later in the year.

Similarly, research has shown that the abundance of euphausiids and copepods and the production of fecal pellets is strongly dependent on the seasonal cycle of primary productivity (Small et al., 1983; Knauer and Martin, 1981; Honjo, 1980). During high phytoplankton production periods, food is consumed by crustaceans at fast rates for storage to allow survival during overwintering, and for reproduction. High numbers of phytoplankton in the surface water coupled with intense feeding by zooplankton result in large exports of fecal pellets to the midwater.

In general, the stomach contents of $P$. meseres appear to record the seasonal succession of dominant phytoplankton in the surface waters. Peak abundances of the autotrophic pennate diatom, Pseudonitzschia australis in the stomachs of $P$.meseres during September and October coincided with unusually high numbers of $P$. australis in the surface waters of Monterey Bay (Buck et al., in prep.). The abundance of the diatom ranged from a high of 2.4 to $27 \times 10^{4}$ cells/ liter during October to a low of 0 at certain times of the year. During the fall 1991, the toxin, domoic acid in P.australis was responsible for over a hundred brown pelican and cormorant deaths in Monterey Bay (Garrison et al., in press). Bolin and Abbott (1963) showed similar peaks of Nitzschia spp. during the Oceanic period (September and October) over a six-year period.

High numbers of autotrophic centric diatoms, Chaetoceros spp. and Skeletonema spp. in the stomachs of $P$. meseres during the Upwelling period corresponded with high peaks during June and July in Monterey Bay from 1954-1960 (Bolin and Abbott, 1963). 
By contrast, diatom peaks in March and April during the present study were not observed in the stomachs of $P$. meseres. The lack of diatoms in the stomachs at this time may be due to heavy grazing by zooplankton in the surface waters.

High numbers of euphausiid fecal pellets in the diet of $P$. meseres during the Upwelling period may be due not only to heavy grazing but also to physical processes in the water column. Euphausiid fecal pellets can sink through the water column at rates up to $1000 \mathrm{~m} \mathrm{day}^{-1}$, but Alldredge et al. (1987) observed high numbers of fecal pellets remaining in the water column during autumn and winter. It was hypothesized that they do not sink immediately, but accumulate in the mixed layer due to turbulent mixing. The Upwelling period is characterized by mixing of different temperature gradients in the water column. Winter mixing may act as a mechanism to sustain fecal pellets and other detrital material in the water column. In comparison, the temperature regime of the Oceanic period is characterized by little mixing and high thermal stratification. During this time, fecal pellets may sink rapidly through the water column, perhaps being less available for consumption.

\section{Food Availability}

The types of food items in the stomachs of $P$. meseres generally reflected what was found in the synoptic water samples. When pennate diatoms were the dominant item in the water samples, high numbers were also found in the stomach contents.

Examination by light microscopy indicated that diatom cells in the water column samples tended to be in chains more frequently than those found in the stomachs. Similarly, fecal pellets tended to be intact more frequently than those in the stomachs. This suggests that $P$. meseres breaks up food items during ingestion.

Mobile ciliates found in the water samples were never observed in the stomach samples of $P$.meseres. Since many ciliates do not have hard tests, they probably would 
not show up in the stomach contents. Motile organisms such as dinoflagellates and ciliates may be attracted to substrates of detrital material after encountering them through random swimming movements (Silver et al., 1978). Ciliates may escape from the substrate of food items ingested by P. meseres. With the exception of dinoflagellates, most of the food items in the stomachs of $P$.meseres were non-motile.

Percent similarity index comparisons of stomach contents to water samples support the hypothesis that $P$. meseres is opportunistic and consumes the organisms and detrital material that is available in the water column. High similarities to water samples collected during July and low similarity values of these same stomach samples to water samples collected during September, October and November indicate that $P$. meseres eats a wide variety of food depending on its availability.

There were several potential problems that may have biased the results in comparing the stomach contents to the water column samples. One water sample per dive may have been inadequate to characterize the water column sufficiently; large fast sinking fecal pellets and other material could not have been adequately sampled by the water bottle. This was evident in the lack of fecal pellets in some water samples. 


\section{LITERATURE CITED}

Alldredge, A.L. 1977. House morphology and mechanisms of feeding in the Oikopleuridae (Tunicata: Appendicularia). J. Zool. (London) 181:175-188.

Alldredge, A.L. 1981. The impact of appendicularian grazing on natural food concentrations in situ. Limnol. Oceanogr. 26:247-260.

Alldredge, A.L. and L. P. Madin. 1982. Pelagic tunicates: Unique herbivores in the marine plankton. Bioscience. 32:655-657.

Alldredge, A. L. 1984. The quantitative significance of gelatinous zooplankton as pelagic consumers. In Fasham, M.J.R. (ed.), Flows of Energy and Materials in Marine Ecosystems: Theory and Practice. Plenum, New York. pp. 407-433.

Alldredge, A.L. C.C. Gotschalk and S. MacIntyre. 1987. Evidence for sustained residence of macrocrustacean fecal pellets in surface waters off Southern California. Deep-sea Res. 34(9): 1641-1652.

Alldredge, A.L. and M.W. Silver. 1988. Characteristic, dynamics and significance of marine snow. Prog. Oceanog. 20: 41-82.

Alldredge, A.L., T.C. Granata, C.C. Gotschalk and T.D.Dickey. 1990. The physical strength of marine snow and its implications for particle disaggregation in the ocean. Limnol. Oceanogr. 35(7): 1415-1428.

Anderson, E.A. 1974. Trophic interactions among ctenophores and copepods in St. Margarets Bay, nova Scotia, Ph.D Dissertation, Dalhousie University.

Barham, E.G. 1957. The ecology of sonic scattering layers in the Monterey Bay area. Phd. Thesis. Stanford University, California.

Barnes, A.T., L.B. Quetin, J.J. Childress and D.L. Pawson. 1976. Deep-sea macroplanktonic sea cucumbers: Suspended sediment feeders captured from deep submergence vehicle. Science 194:1083-1085.

Barnes, R.D. 1980. Invertebrate Zoology, 4th edition. Saunders College, Philadelphia, Pennsylvania.

Berkeley, E. and C. Berkeley. 1960. Some further records of pelagic polychaeta from the Northeast Pacific north of latitude 40 degrees $\mathrm{N}$ and east of longitude 175 degrees W, together with records of Siphonophora, Mollusca, and Tunicata from the same region. Canad. J. Zool. 38:787-799.

Biggs, D.C. 1976. Nutritional ecology of Agalma okeni, in: Coelenterate Ecology and Behavior, ed. G.O. Mackie, Plenum Press, New York.

Biggs, D.C., R.R. Bidigare and D.E. Smith. 1981. Population density of gelatinous macrozooplankton: In situ estimation in oceanic surface waters, Biol. Oceanogr. 1: $157-167$. 
Billett, D.S.M., R.S. Lampitt, A.L. Rice and R.F.C. Mantoura. 1983. Seasonal sedimentation of phytoplankton to the deep-sea benthos. Nature. 302 (7): 520522 .

Bishop, J.K.B. R.W. Collier, D.R. Kettens and J.M. Edmond. 1980. The chemistry, biology and vertical flux of particulate matter from the upper $1500 \mathrm{~m}$ of the Panama Basin. Deep-sea Res. 27A: 615-640.

Bolin, R.L. and D.P. Abbott. 1963. Studies on the marine climate and phytoplankton of the central coastal area of California, 1954-1960. CalCOFI Rep. 9.

Buck, K.R. , Uttal-Cooke, L., C.H. Pilskaln, D.L. Roelke, C. Villac, G.A. Fryxell, L. Cifuentes and F.P. Chavez. Autoecology of Pseudonitzschia australis Frenguelli, a suspected domoic acid producer, from Monterey Bay, California. (in press).

Cailliet, G.M. and A.W. Ebeling. 1990. The vertical distribution and feeding habits of two common midwater fishes (Leuroglossus stilbius and Stenobrachius leucopsarus) off Santa Barbara. CalCOFI Rep. 31: 106-123.

Dales, R.P. 1955. Feeding and digestion in terebellid polychaetes. J. Mar. Biol. Ass. U.K. 34: 54-79.

Dales, R.P. 1963. Annelids. Hutchinson University Library, London.

Dales, R.P. and G. Peter. 1972. A synopsis of pelagic polychaetes. J. Nat. Hist. 6(1):5592.

Deibel, D.R. 1980. Feeding, growth and swarm dyamics of neritic tunicates from the Georgia Bight, Ph.D. Dissertation, University of Georgia.

Deibel, D.R. 1986. Feeding mechanism and house of the appendicularian Oikopleura vanhoeffeni. Mar. Bio. 93:429-436.

Eppley, R.W. , F.M.H. Reid and J.D.R.Strickland. 1970. Estimates of phytoplankton crop size, growth rates and primary productivity. In J.D.R. Strickland(ed.), The ecology of the phytoplankton off La Jolla, California in the period April through September, 1967. Bull. Scripps Insti. Oceanogr. 17:33-42.

Fisher, W.K. 1946. Echiuroid worms of the North Pacific Ocean. Proc. U.S. Nat. Mus. 96:215-292.

Fowler, S.W. and L.F. Small. 1972. Sinking rates of euphausiid fecal pellets. Limnol. Oceanogr. 17: 293-296.

Frankenberg, D. and Smith, K.L. 1967. Copraphagy in marine animals. Limnol. Oceanogr. 12: 433-450.

Gilmer, R. W. 1972. Free floating mucous webs: A novel feeding adaptation for the open ocean. Science 176:1239-1240. 
Gowing M.M. and S.L. Coale. 1989. Fluxes of living radiolarians and their skeletons along a northeast Pacific transect from coastal upwelling to open ocean waters. Deep-sea Res. 36(4): 561-576.

Gowing, M.M. and M.W. Silver. 1985. Minipellets: a new and abundant size class of marine fecal pellets. J. of Mar. Res. 43: 395-418.

Grasse, P.P. 1959. Traite de Zoologie 5. Paris: Masson et Cie Ed.

Gremare, A. 1988. Feeding, tube-building and particle-size selection in the terebellid polychaete Eupolymnia nebulosa. Mar. Biol. 97: 243-252.

Hamner, W.M., L.P. Madin, A.L. Alldredge, R.W. Gilmer and P.P. Hamner. 1975. Underwater observations of gelatinous zooplankton: Sampling problems, feeding biology, and behavior. Limnol. and Oceanogr. 20(6): 907-917.

Harbison, G.R., L.P. Madin and N.R. Swanberg. 1978. On the natural history and distribution of oceanic ctenophores, Deep Sea Res. 25: 233-256.

Harding, G.C.H. 1974. The food of deep sea copepods. J. mar. biol. Ass. U.K. 54:141155.

Heath, H. 1930. A connecting link between the Annelida and the Echiroidea (Gephyrea armata). J. Morph. Physiol. 49:223-249.

Hartman, 1955. Endemism in the North Pacific with emphasis on the distribution of marine annelids, and descriptions of new or little known species. Essays in the Natural Science in Honor of Captain Allan Hancock. Univ. of S. California Press, Los Angeles. pp. 39-61.

Hirota, J.,1974. Quantitative natural history of Pleurobrachia bachei in La Jolla Bight. Fish. Bull. 72:295-300.

Honjo, S., and M.R. Roman. 1978. Marine copepod fecal pellets: production preservation and sedimentation. J. Mar. Res. 36: 45-57.

Honjo, S. 1980. Material fluxes and modes of sedimentation in the mesopelagic and bathypelagic zones. J. Mar. Res. 38: 53-97.

Hurturbia, J. 1973. Trophic diversity measurement in sympatric predatory species. Ecology 54(4) 885-890.

Ikeda, T. 1984. Sequences in metabolic rates and elemental composition (C,N,P) during the development of Euphausia superba Dana and estimated food requirements during its life span. J. Crustacean Biol. 4 (1): 278-284.

Jorgensen, C.B. 1981. Effect of Grazing: Metazoan suspension feeders. In: Heterotrophic activity in the sea, JE. Hobbie and P.J. leb. Williams. Ed. Plenum Press, New York. 
Knauer, G.A., and J.H. Martin. 1981. Primary productivity and carbon-nitrogen fluxes in the upper $1500 \mathrm{~m}$ of the northeast Pacific. Limnol. Oceanogr. 26, 97-108.

Kovala, P.E. and Larrance, J.D. 1966. Formulas for computing area, the volume and the plasma volume of a Phytoplankton cell. From Dave Garrison, UCSC.

Lampitt, T.Noji and B. von Bodungen. 1990. What happens to zooplankton faecal pellets? Implications for material flux. Mar. Biol. 104: 15-23.

Larson, R., 1978. Feeding and functional morphology of scyphomedusae. M.A. Thesis. University of Puerto Rico.

Madin, L.P. 1974. Field observations on the feeding biology behavior of salps (Tunicata: Thaliacea). Mar. Biol., 25: 143-147.

Madin, L.P. and C.M. Cetta. 1984. The use of gut fluorescence of salp fecal pellets in oceanic waters. Mar. Biol. 67: 475-492.

Martens, P. 1978. Faecal pellets. In Fiches D'identifications du zooplancton 162. Ed. J.H. Fraser. Charlottenlund, Denemark.

Martin, J. H., G.A. Knauer, D.M. Karl and W.W. Broenkow. 1987. VERTEX: Carbon cycling in the northeast Pacific. Deep-sea Res. 34(2): 267-285.

McGowan, 1960. The relationship of the distribution of the planktonic worm, Poeobius meseres Heath, to the water masses of the North Pacific. Deep-sea Res. 6:125139.

Michaels, A.F. and M.W. Silver. 1988. Primary production, sinking fluxes and the microbial food web. Deep-Sea Res. 35(4) 473-490.

Mullin, M.M., P.R. Sloan and R.W. Eppley. 1966. Relationships between carbon content, cell volume, and area in phytoplankton. Limnol. Oceanogr. 11:307-311.

Paffenhofer, G.A. and J.D.H. Strickland. 1970. A note on the feeding of Calanus helgolandicus on detritus. Mar. Biol. 5: 97-99.

Paffenhofer, G.A. and S.C. Knowles. 1979. Ecological implications of fecal pellet size, production and consumption by copepods. J. Mar. Res. 37:35-49.

Pickford, G.E. 1947. Histological and histochemical observations upon an aberrant annelid Poeobius meseres Heath. J. Morph. 80(3):287-319.

Pinkas, L., M.S. Oliphant and I.L. Iverson. 1971. Food habits of albacore, bluefin tuna and bonito in California waters. Calif. Fish Game. Fish. Bull. 152:1-105.

Pilskaln, C.H. and S. Honjo. 1987. The fecal pellet fraction of biogeochemical particle fluxes to the deep sea. Global biogeochemical cycles. 1(1): 31-48.

Purcell, J.E. 1981a. Selective predation and caloric consumption by the siphonophore Rosaceae cymbiformis in nature. Mar. Biol., 63:283-294. 
Purcell, J.E. 1981b. Feeding ecology of Rhizophysa eysenhardtii, a siphonophore predator of fish larvae. Limnol. Oceanogr. 26: 424-432.

Purcell, J.E. 1982. Feeding and growth in the siphonophore Muggiaea atlantica (Cunningham). J. Exp. Mar. Biol. Ecol. 62:39-54.

Purcell, J.E. and P. Kremer. 1983. Feeding and metabolism of the siphonophore Sphaeronectes gracilis. J. Plankton Res. 5:95-106.

Robbins, D.E. 1965. The biology and morphology of the pelagic annelid Poeobius meseres Heath. J. Zool. 140: 197-212.

Rogers, C.A., D.C. Biggs and R.A. Cooper. 1978. Aggregation of the siphonophore Nanomia cara in the Gulf of Maine: Observations from a submersible. United States National Marine Fisheries Service Fishery Bulletin 76: 281-290.

Sancetta, C. and S.E. Calvert. 1988. The annual cycle of sedimentation in Saanich Inlet, British Columbia: implications for the interpretation of diatom fossil assemblages. Deep-sea Res. 35(1): 71-90.

Sanders, H.L. 1960. Benthic studies in Buzzards Bay III. The structure of the soft-bottom community. Limnol. and Oceanogr. 5(2):138-153.

Seapy, R. R. 1980. Predation by the epipelagic heteropod mollusk Carinaria cristata forma japonica. Mar. Biol. 60:137-146.

Seki, H. 1973. Red tide of Oikopleura in Saanich Inlet. Bull. Soc. Francojap. Oceanogr. 11:153-162.

Silver, M.W., A.L. Shanks \& J.D. Trent. 1978. Marine Snow: microplankton habitat and source of small-scale patchiness in pelagic populations. Science. 201:371-373.

Silver, M.W. and A.L. Alldredge. 1981. Bathypelagic marine snow: deep-sea algal and detrital community. J. of Mar. Res. 39 (3): 501-530.

Silver, M.W. and M.M. Gowing. 1991. The "Particle" flux: Origins and biological components. Prog. Oceanog. 26: 75-113.

Small, L.F., S.W. Fowler, S.A. Moore and J. LaRosa. 1983. Dissolved and fecal pellet carbon and nitrogen release by zooplankton in tropical waters. Deep-sea res. 30(12a): 1199-1220.

Sokal, R.R. and F.J. Rohlf. 1969. Biometry, The Principles and Practice of Statistics in Biological Research. Second edition. W.H. Freeman and Co., San Francisco.

Suess, E. 1980. Particulate organic carbon flux in the oceans-surface productivity and oxygen utilization. Nature. 288:260-263.

Strathmann, R.R. 1967. Estimating the organic content of phytoplankton from cell volume or plasma volume. Limnol. Oceanogr. 12:411:418. 
Theil, H., O. Pfannkuches, G. Schriever, K. Lochte, A.J.Gooday, CH. Hemleben, R.F.G.Mantoura, C.M.Turley, J.W.Patching and F. Riemann. 1989. Phytodetritus on the deep-sea floor in a central oceanic region of the Northeast Atlantic. Biological Oceanography 6: 203-239.

Turner, J.T. and J.A. Ferrante. 1979. Zooplankton fecal pellets in aquatic ecosystems. Bioscience 29: 670-677.

Turner, J.T. 1986. Zooplankton feeding ecology: Contents of fecal pellets of the copepod Undinula vulgaris from Continental shelf waters of the Gult of Mexico. Mar. Ecol. 7(1) 1-14.

Turner, J.T. 1991. Zooplankton feeding ecology: Do Co-occurring Copepods Compete for the Same Food? Reviews in Aquatic Sciences 5(2): 101-195.

Vinagradov, M.E. 1962. Feeding of deep-sea zooplankton. Rapp. P-V Reun. Cons. Perm. Int. Explor. Mer. 153: 114-120. 


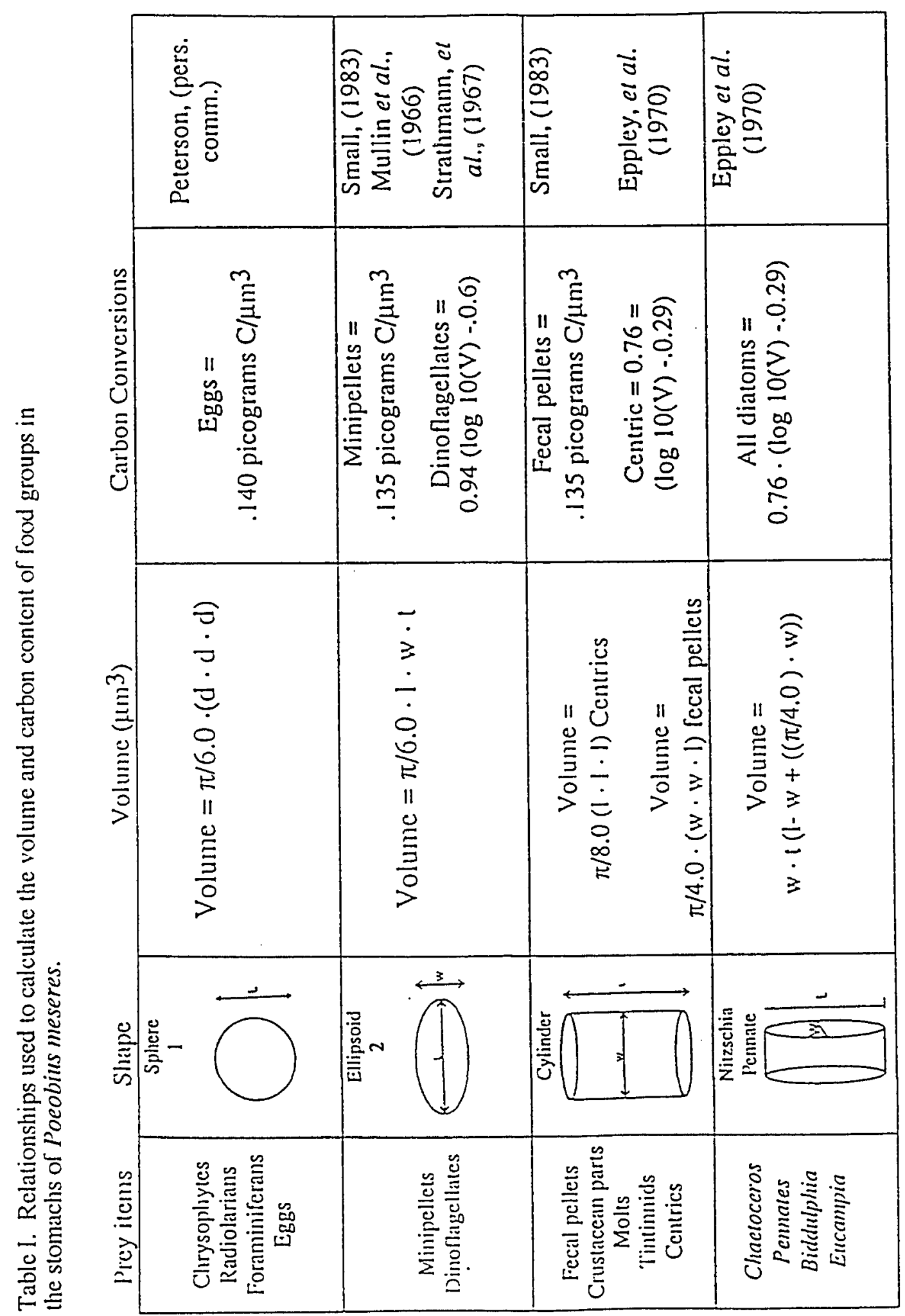


Table 2. Food items found in the stomach contents of P. meseres. Food items (in bold) are the major food groups with more specific taxa listed below.

\section{Fecal pellets}

Minipellets

Crustacean parts

Whole moults

Tintinnids

Centric diatoms

Thalassiosira spp.

Coscinodiscus spp.

Rhizosolenia spp.

Chaetocerus spp.

Ditylum spp.

Skeletonema spp.

Dactylosolen spp.

Pennate Diatoms

Nitzschia spp.

Navicula spp.

Pleurosigma spp.

Pseudoenotia spp.

Amphora spp.

Sururiella spp.

Grammatophora spp.

Dinoflagellates

Thecate dinoflagellates

Athecate dinoflagellates

Frotoperidinium spp.

Dinophysis spp.

Chrysophytes

Dictyocha spp.

Distephanus spp.

Radiolarians

Acantharians

Phaeodarians

Spumellarians

Nasellarians

Foraminiferans

Eggs

Globigerina spp. 
TABLE 3. Values for total composition of major food groups in the 62 stomachs of $P$. meseres. (Mean \%number +mean \%volume) $\mathrm{x}$ (\% frequency of occurrence) $=$ Index of Relative Importance (IRI).

\begin{tabular}{|c|c|c|c|c|}
\hline PREY ITEMS & $\begin{array}{c}\text { Mean \%N } \\
( \pm \mathbf{S E})\end{array}$ & $\begin{array}{c}\text { Mean \%V } \\
( \pm \text { SE) }\end{array}$ & \%FO & IRI \\
\hline Fecal pellets & $30(3.0)$ & $58(4.5)$ & 98 & 8694 \\
\hline Centric diatoms & $25(2.8)$ & $16(3.7)$ & 97 & 3960 \\
\hline Pennate diatoms & $33(3.3)$ & $2(.77)$ & 94 & 3306 \\
\hline Crustacean parts & $2.0(.4)$ & $17(3.1)$ & 79 & 1400 \\
\hline Minipellets & $7.1(1.4)$ & $1.7(1.3)$ & 79 & 689 \\
\hline Tintinnids & $1.3(.33)$ & $2.4(.94)$ & 65 & 241 \\
\hline Dinoflagellates & $.74(.23)$ & $.10(.03)$ & 45 & 37 \\
\hline Radiolarians & $.11(.04)$ & $.75(.62)$ & 16 & 14 \\
\hline Foraminiferans & $.18(.05)$ & $.23(.12)$ & 24 & 10 \\
\hline Whole crustaceans & $.01(.005)$ & $1.1(1.0)$ & 3.2 & 4 \\
\hline Eggs & $.14(.12)$ & $.27(.2)$ & 4.8 & 2 \\
\hline Chrysophytes & $.03(.01)$ & $.001(.0005)$ & 10 & .3 \\
\hline
\end{tabular}


TABLE 4. Values for the composition of major food groups in the stomachs of $P$. meseres for the three oceanographic seasons. Calculations for IRI are the same as for TABLE3.

DAVIDSON PERIOD

\begin{tabular}{|c|c|c|c|c|}
\hline PREY ITEMS & $\begin{array}{c}\text { Mean \%N } \\
( \pm S E)\end{array}$ & $\begin{array}{c}\text { Mean \% V } \\
( \pm S E)\end{array}$ & IRI \\
\hline Fecal pellets & $27(4.9)$ & $73(6.9)$ & 100 & 9960 \\
\hline Pennates diatoms & $41(5.4)$ & $2.1(.44)$ & 95 & 4114 \\
\hline Centrics diatoms & $15(3.4)$ & $1.7(.48)$ & 95 & 1575 \\
\hline Minipellets & $13(3.8)$ & $<1(.2)$ & 84 & 1120 \\
\hline Crustacean parts & $2.0(.90)$ & $17(6.0)$ & 58 & 1095 \\
\hline Tintinnids & $2.0(.80)$ & $3.9(2.4)$ & 58 & 317 \\
\hline Foraminilerans & $.27(.13)$ & $.43(.30)$ & 26 & 18 \\
\hline Radiolarians & $.21(.13)$ & $.35(.29)$ & 21 & 12 \\
\hline Dinollagellates & $.34(.19)$ & $.03(.02)$ & 26 & 10 \\
\hline Egas & $.07(.07)$ & $.52(.52)$ & 5.3 & 3 \\
\hline Chrysophytes & $.01(.03)$ & $.05(.05)$ & 5.3 & .3 \\
\hline Whole crustaceans & $0(0)$ & $0(0)$ & 0 & 0 \\
\hline
\end{tabular}

UPWELLING PERIOD

\begin{tabular}{|c|c|c|c|c|}
\hline PREY ITEMS & $\begin{array}{c}\text { Mean \%N } \\
( \pm S E)\end{array}$ & $\begin{array}{c}\text { Mean \%V } \\
( \pm S E)\end{array}$ & \%FO & IRI \\
\hline Fecal pellets & $40(3.9)$ & $53(5.9)$ & 97 & 8997 \\
\hline Centrics diatoms & $33(3.9)$ & $20(5.4)$ & 100 & 5359 \\
\hline Crustacean parts & $2.4(0.5)$ & $21(4.7)$ & 85 & 2024 \\
\hline Pennate diatoms & $16(1.6)$ & $.24(.05)$ & 97 & 1612 \\
\hline Minipellets & $5.1(1.2)$ & $2.6(2.36)$ & 85 & 649 \\
\hline Tintinnids & $1.5(.42)$ & $1.1(.43)$ & 76 & 191 \\
\hline Dinoflagellates & $1.1(.41)$ & $.13(.051$ & 36 & 46 \\
\hline Radiolarians & $.08(.04)$ & $1.2(1.2)$ & 15 & 19 \\
\hline Foramimlerans & $.18(.06)$ & $.18(.15)$ & 30 & 11 \\
\hline Whole Crustaceans & $.01(.01)$ & $.06(.03)$ & 3 & .21 \\
\hline Egors & $.01(.01)$ & $.01(.01)$ & 3 & .003 \\
\hline Chrysophytes & $.001(.01)$ & $.02(.02)$ & .001 & 0 \\
\hline
\end{tabular}

\section{OCEANIC PERIOD}

\begin{tabular}{|c|c|c|c|c|}
\hline PREY ITEMS & $\begin{array}{c}\text { Mean \%N } \\
( \pm \text { SE) }\end{array}$ & $\begin{array}{c}\text { Mean \%V } \\
( \pm \text { SE) }\end{array}$ & \% FO & IRI \\
\hline Pennate diatoms & $72(6.7)$ & $10(3.9)$ & 100 & 8276 \\
\hline Fecal pellets & $7.7(2.7)$ & $45(13)$ & 100 & 5227 \\
\hline Centric diatoms & $17(7.5)$ & $29(13)$ & 80 & 3638 \\
\hline Tintinnids & $.37(.17)$ & $4.1(3.5)$ & 60 & 267 \\
\hline Crustacean parts & $.40(.3)$ & $4.6(1.7)$ & 50 & 251 \\
\hline Minipellets & $1.4(.8)$ & $.40(.22)$ & 50 & 88 \\
\hline Whole crustaceans & $.02(.02)$ & $6.5(6.5)$ & 10 & 65 \\
\hline Eggs & $.71(.71)$ & $.71(.71)$ & 10 & 14 \\
\hline Dinoflagellates & $.21(.12)$ & $.08(.05)$ & 30 & 9 \\
\hline Radiolarians & $.03(.03)$ & $.01(.01)$ & 10 & 0.4 \\
\hline Chrysophvtes & $.001(.01)$ & $.001(.001)$ & 10 & 0 \\
\hline Chrysophvtes & $.001(0)$ & $.001(.001)$ & 10 & 0 \\
\hline
\end{tabular}




\begin{tabular}{|c|c|c|c|c|c|c|}
\hline 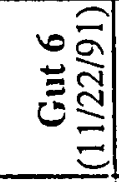 & in & 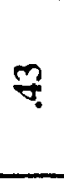 & $\Phi$ & $i$ & Z & $\hat{\theta}$ \\
\hline 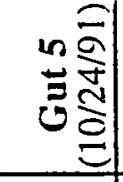 & กี & 节 & గ్ & $\bar{\infty}$ & f. & \\
\hline 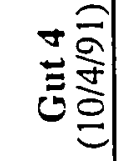 & ขै & $\vec{m}$ & $\infty$ & $\stackrel{\infty}{9}$ & & \\
\hline 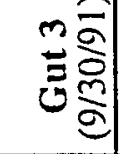 & in & 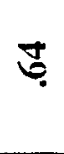 & $\stackrel{\infty}{r}$ & & & \\
\hline 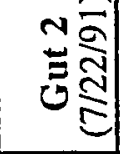 & $?$ & $\stackrel{q}{r}$ & & & & \\
\hline 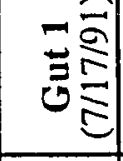 & סீ & & & & & \\
\hline$\overline{\mathscr{L}}$ & $\frac{\square}{\grave{d}}$ & 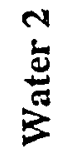 & 站 & $\frac{\nabla}{\frac{\nabla}{5}}$ & $\frac{n}{3}$ & $\frac{0}{3}$ \\
\hline
\end{tabular}




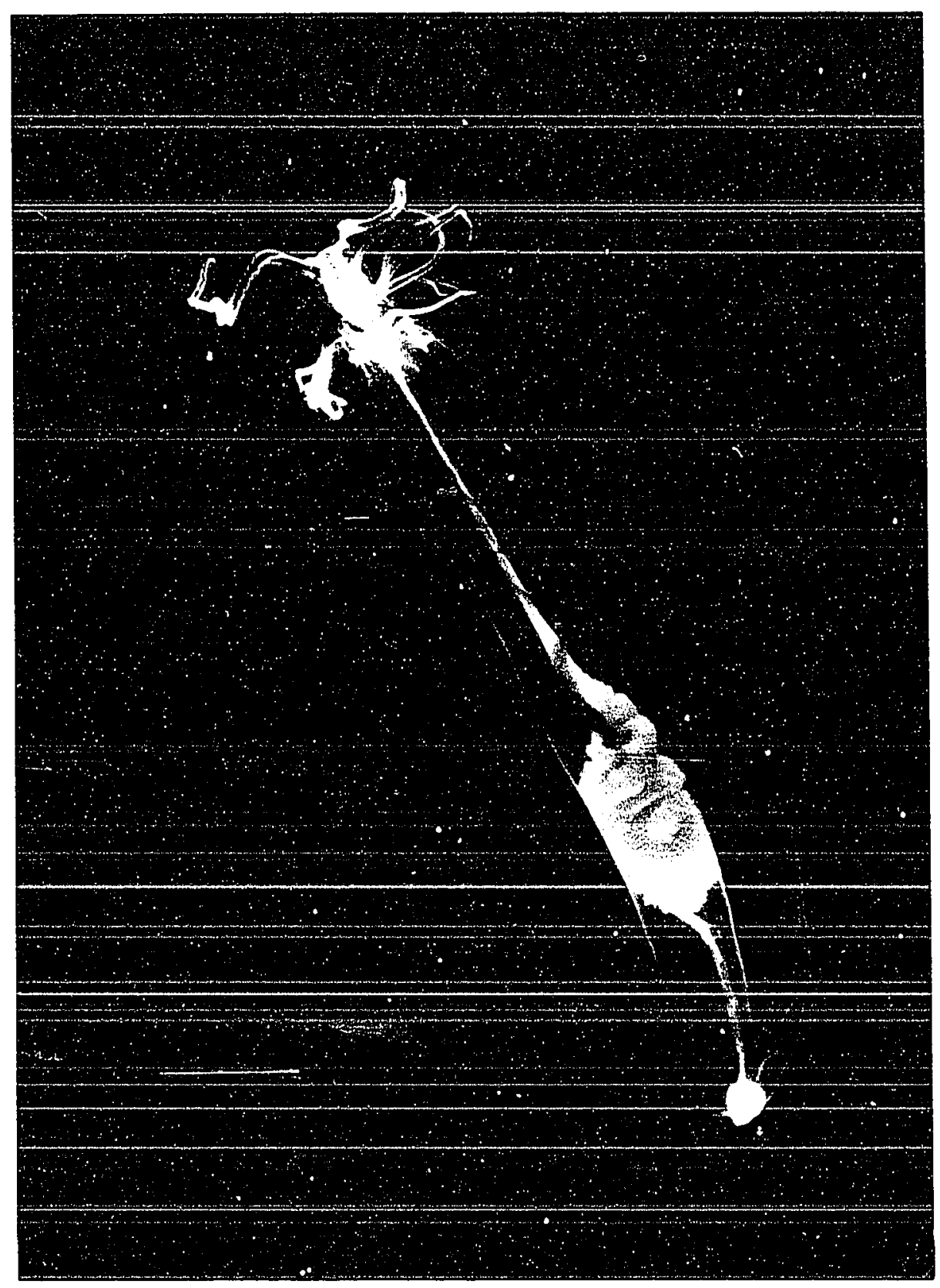

Figure 1. Poeobius meseres. Entire animal with internal organs visible through transparent body wall (Photo copyright Sea Studios, Inc.) 


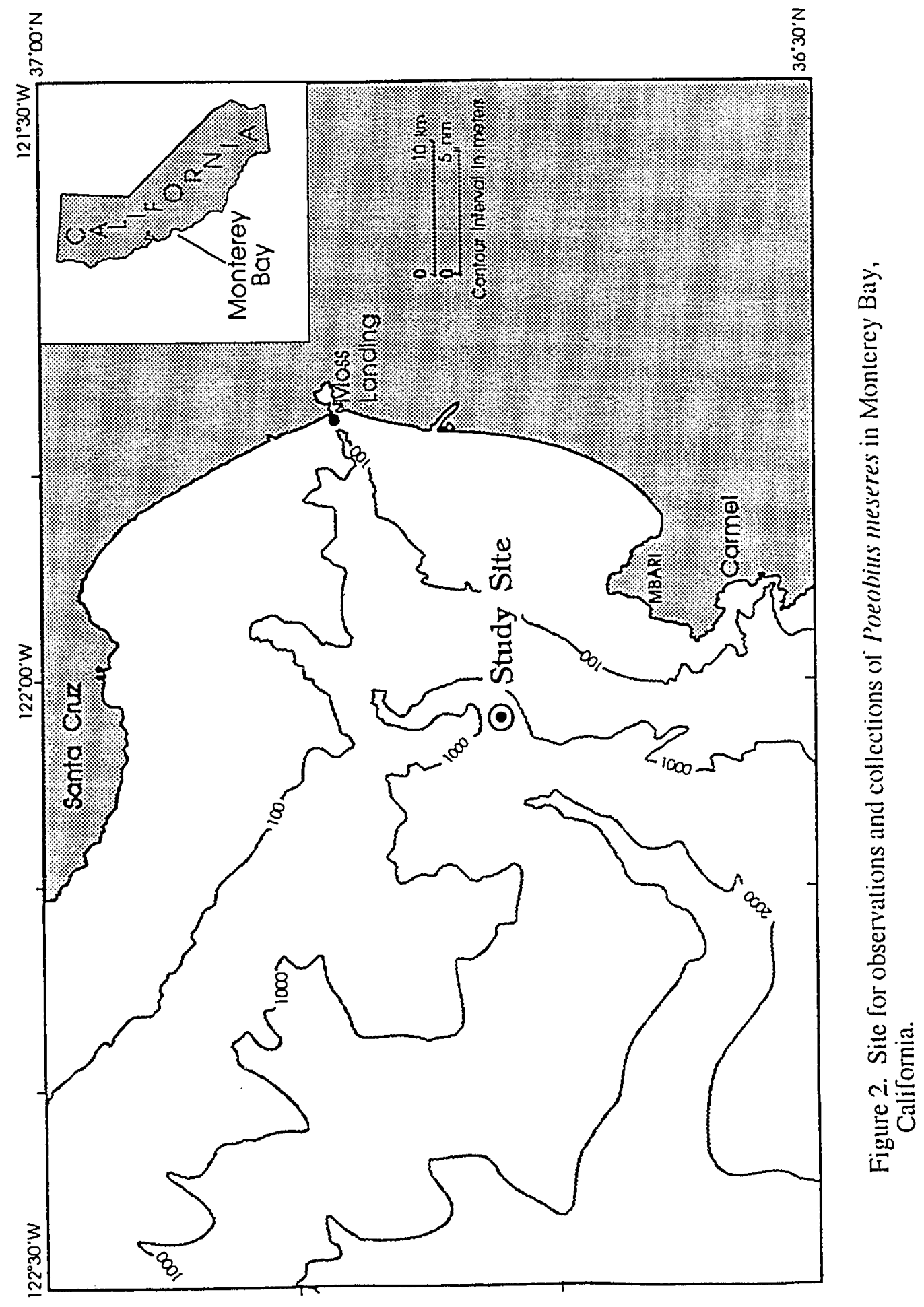



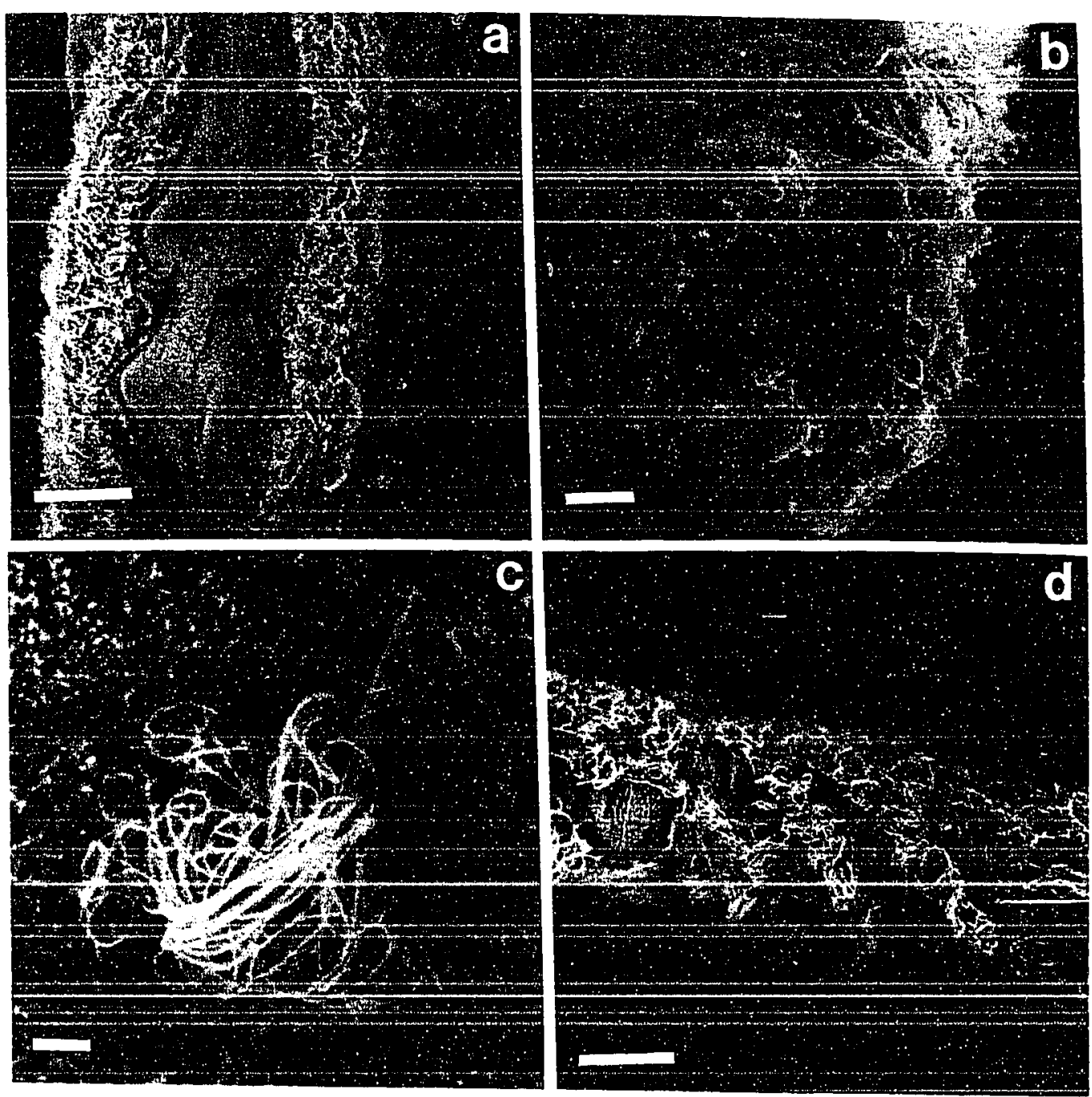

Figure 3. Scanning Electron Microscopy of feeding apparatus in $P$. meseres. The cephalic region is composed of a pair of thick, longitudinally grooved palpi and 5-6 pairs of cirri in a transverse row. a) Section of ciliated grooved palp; scale $=20 \mu \mathrm{m}$. b) Tip of cirri with dense bands of cilia; scale $=15 \mu \mathrm{m}$. c) Ciliary tuft on the lateral cdge of the grooved palp; scale $=2 \mu \mathrm{m}$. d) Section of cirri with diagonal bands of cilia; scale $=20 \mu \mathrm{m}$. 


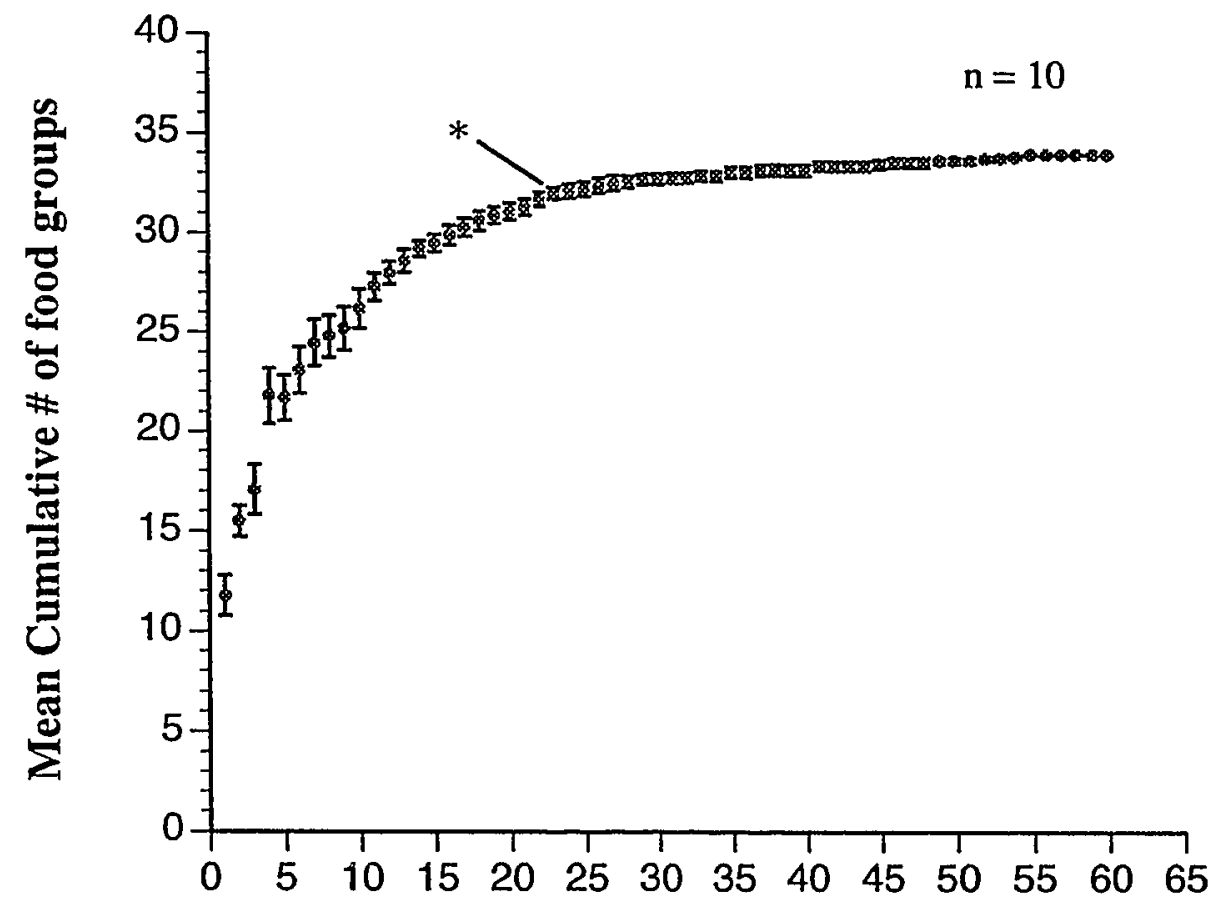

\section{Pooled number of guts}

Figure 4. Cumulative food items versus sample size curve to determine adequacy of sampling of stomachs in $\vec{P}$. meseres over a one year period. Sixty-two stomachs were randomized ten times and the cumulative number of food items measured. The symbols are the mean of these ten randomizations with their associated standard error. The "*" shows the pooled number of stomachs necessary to reach stabilization of the curve. An adequate number of stomachs were sampled to describe the diet of $P$. meseres. 


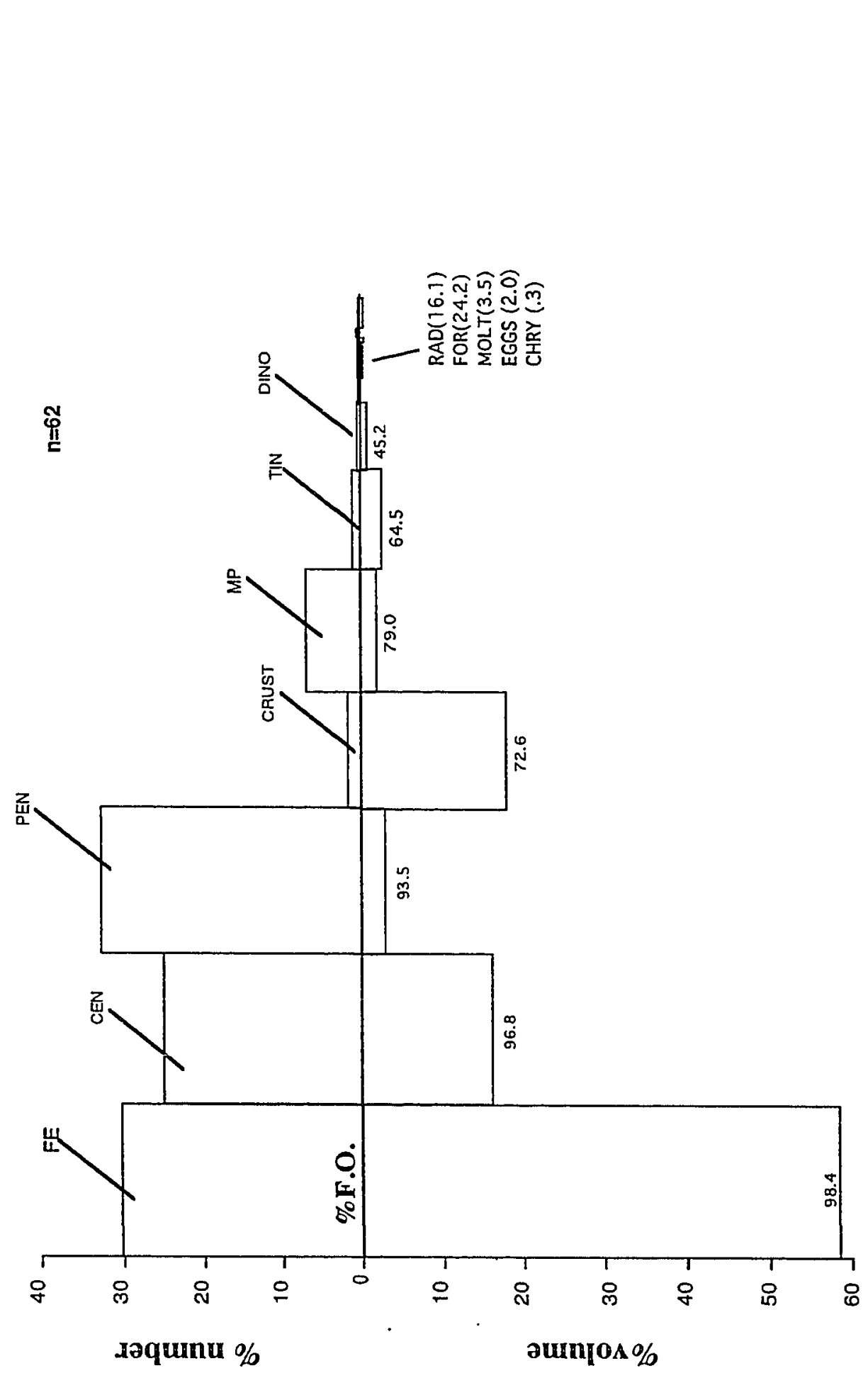

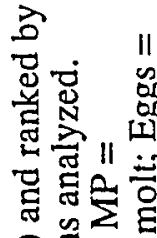

oิ $\bar{c}$ is

동 है

का

8 论

5)

들를렁흥

ठ ㄹ

论落

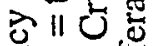

政.

霅

4 궁ㅎㅁ

击

هํํㄹ

要

o

o

定..

즘

R.

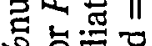
so

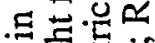

n.

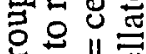

ons

닝

응 in

5。

类

플

\& 8

페

空

음 ․ㅡㄹ

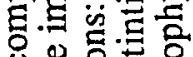

를

可

क它 FII

थ岁完

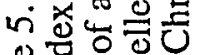

는

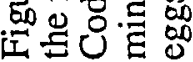



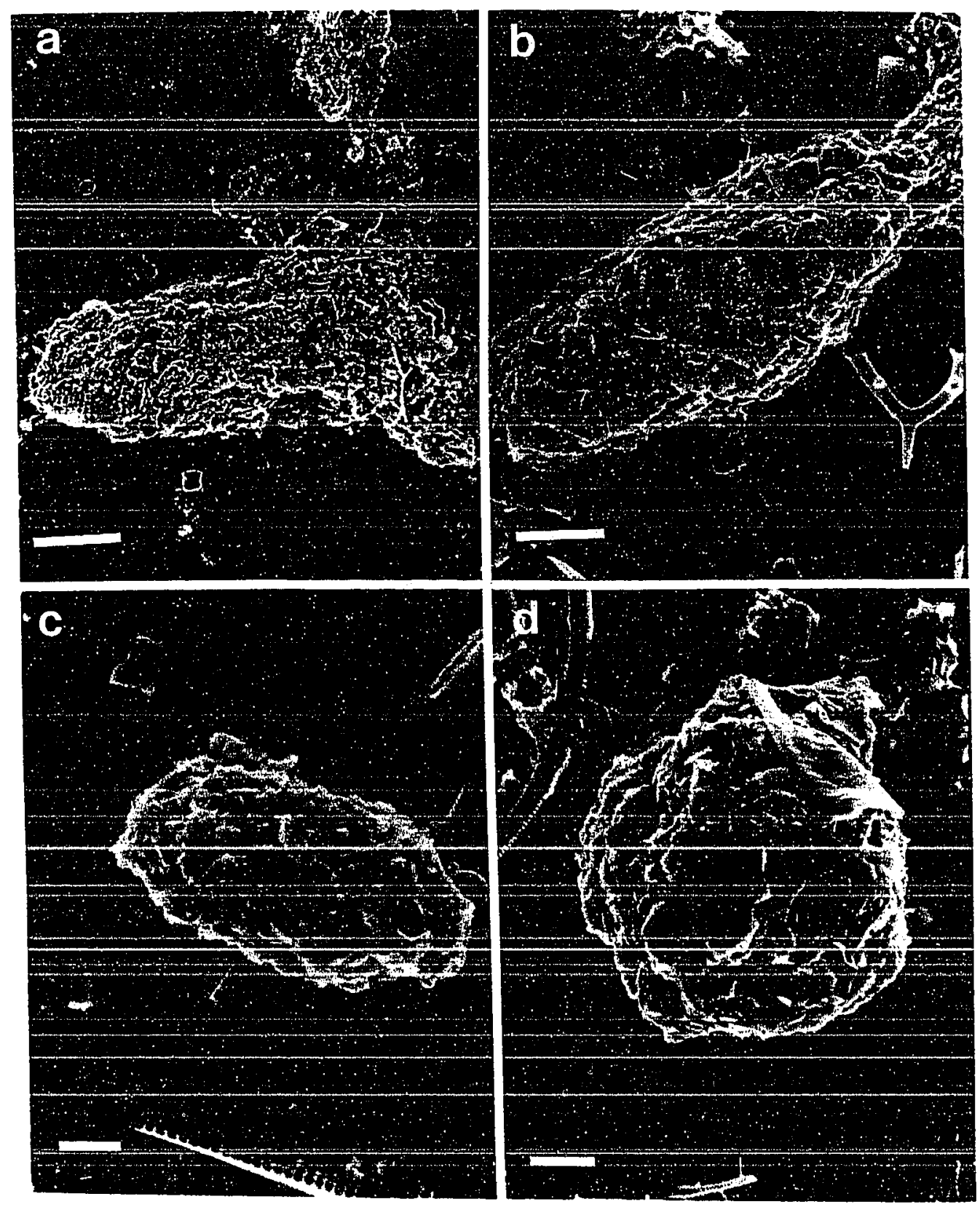

Figure 6. Scanning electron microscopy of fecal pellets in the stomach contents of $P$. meseres. a) Fecal pellet with macerated Thalassiosira sp.; scale $=20 \mu \mathrm{m}$. b) Copepod fecal pellet; scale $=30 \mu \mathrm{m}$. c) Fecal pcllet of unknown origin; scale $=5 \mu \mathrm{m}$. d) Minipellet with digested Nitzschia sp.; scale $=5 \mu \mathrm{m}$. 

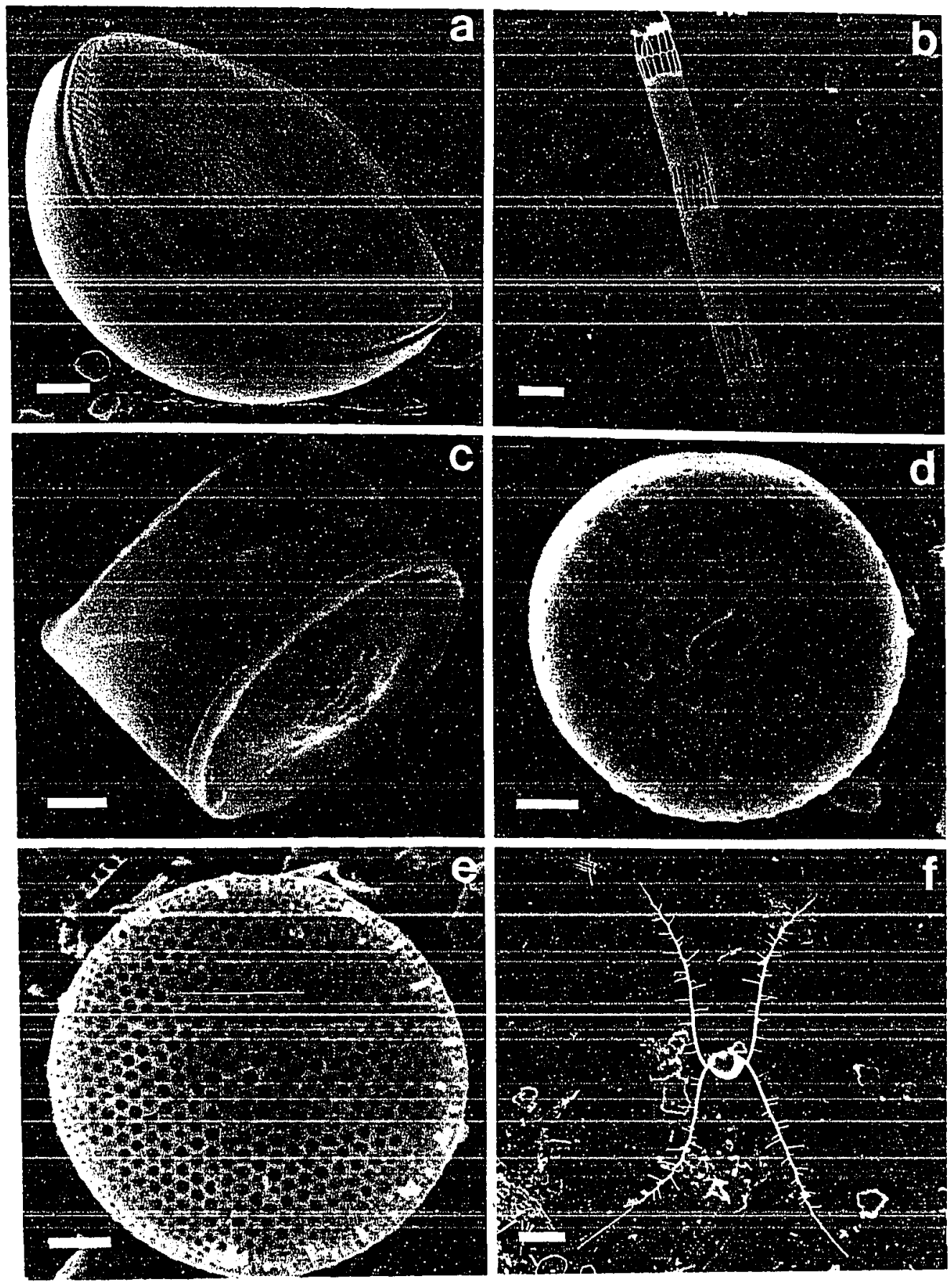

Figure 7. Scanning Electron Microscopy of centric diatoms in the stomachs of $P$. meseres. a) Hemidiscus sp.; scale $=5 \mu \mathrm{m}$. b) Skeletonema sp.; scale $=10 \mu \mathrm{m}$. c) Resting spore of Chaetoceros sp.; scale $=2 \mu \mathrm{m}$; d) Unknown centric diatom; scale $=2 \mu \mathrm{m}$. e) Thalassiosira sp.; scale $=5 \mu \mathrm{m}$. f) Chactoceros sp.; scale $=10 \mu \mathrm{m}$. 

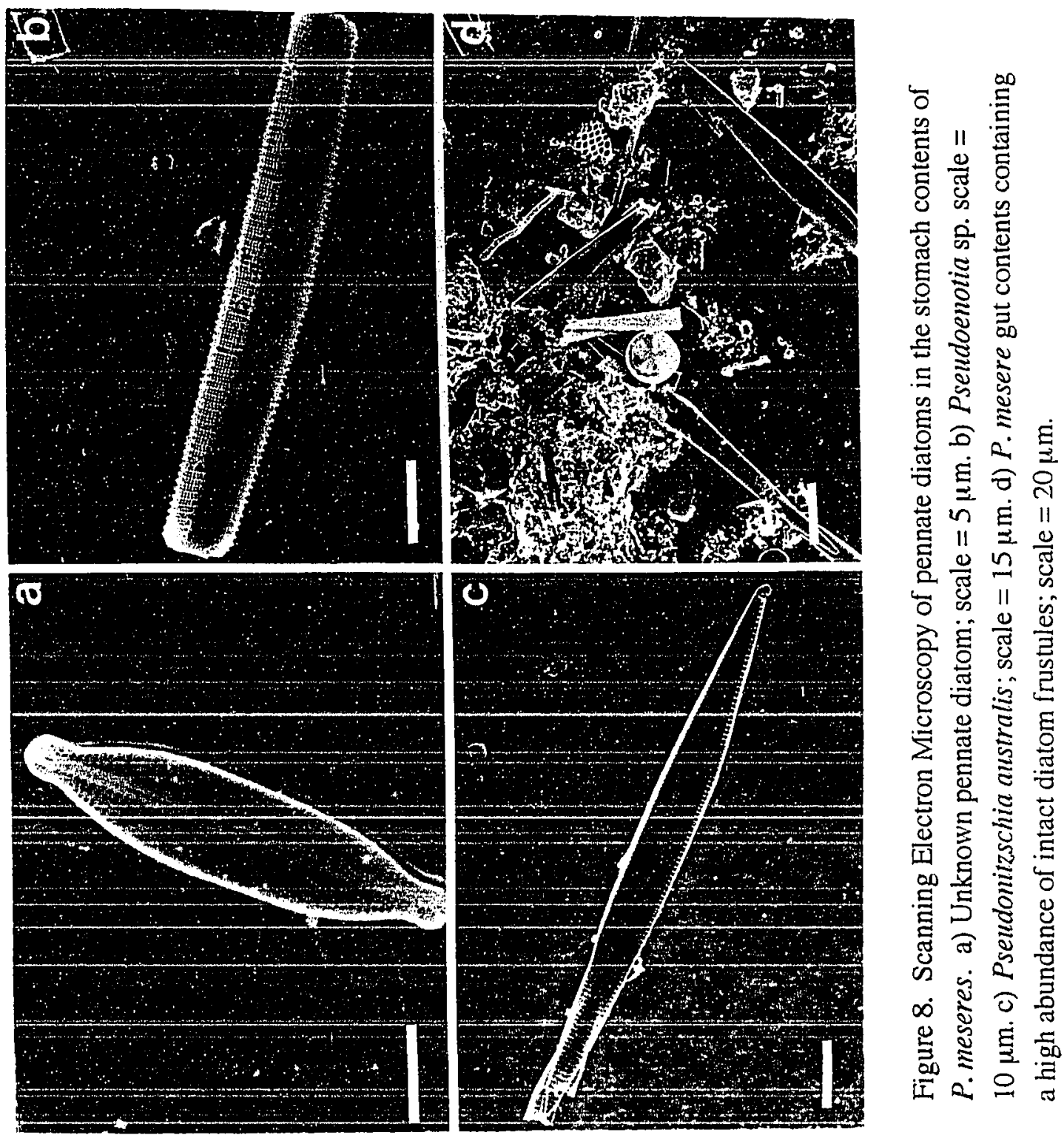

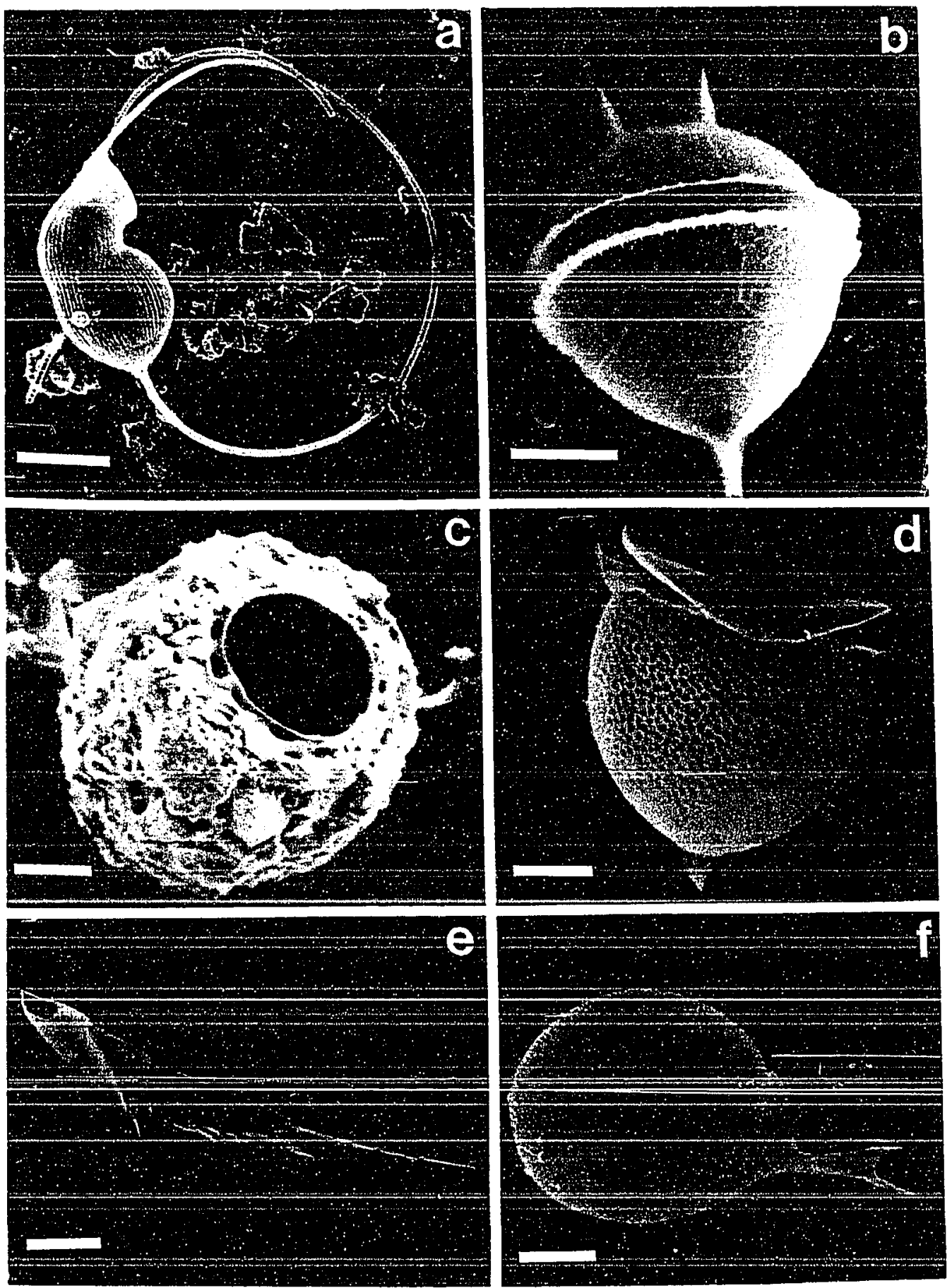

Figure 9. Scanning Electron Microscopy of less abundant prey items in the stomachs of P. meseres. a) Borgetella sp.; scale $=20 \mu \mathrm{m}$. b) Protoperidinium sp.; scale $=10 \mu \mathrm{m} . \mathrm{c}$ ) Tintinnid; scale $=15 \mu \mathrm{m}$. d) Dinophysis sp.; scale $=10 \mu \mathrm{m} . \mathrm{c}) \quad$ Crustacean part; scalc = $50 \mu \mathrm{m}$. 1) Protocystis sp. (Phacodarian); scale $=10 \mu \mathrm{m}$. 
$\mathbf{a}$

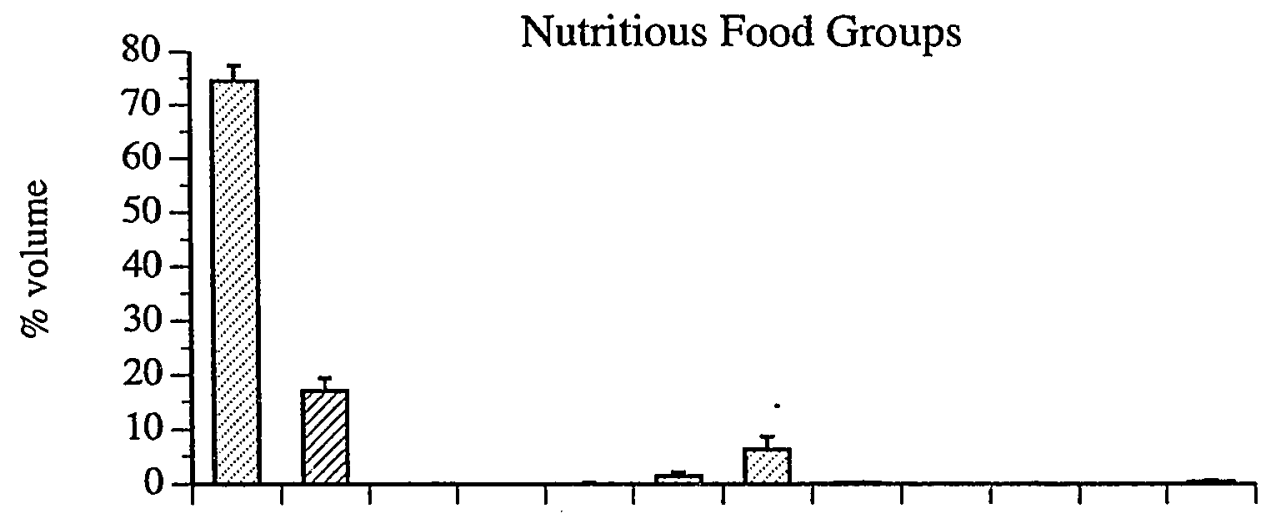

b

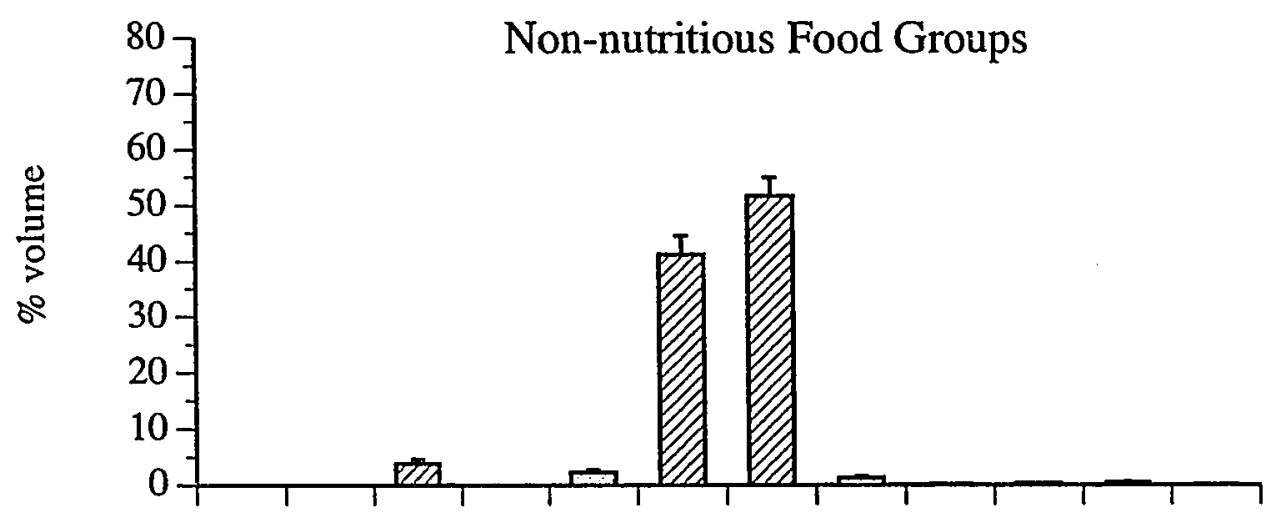

c

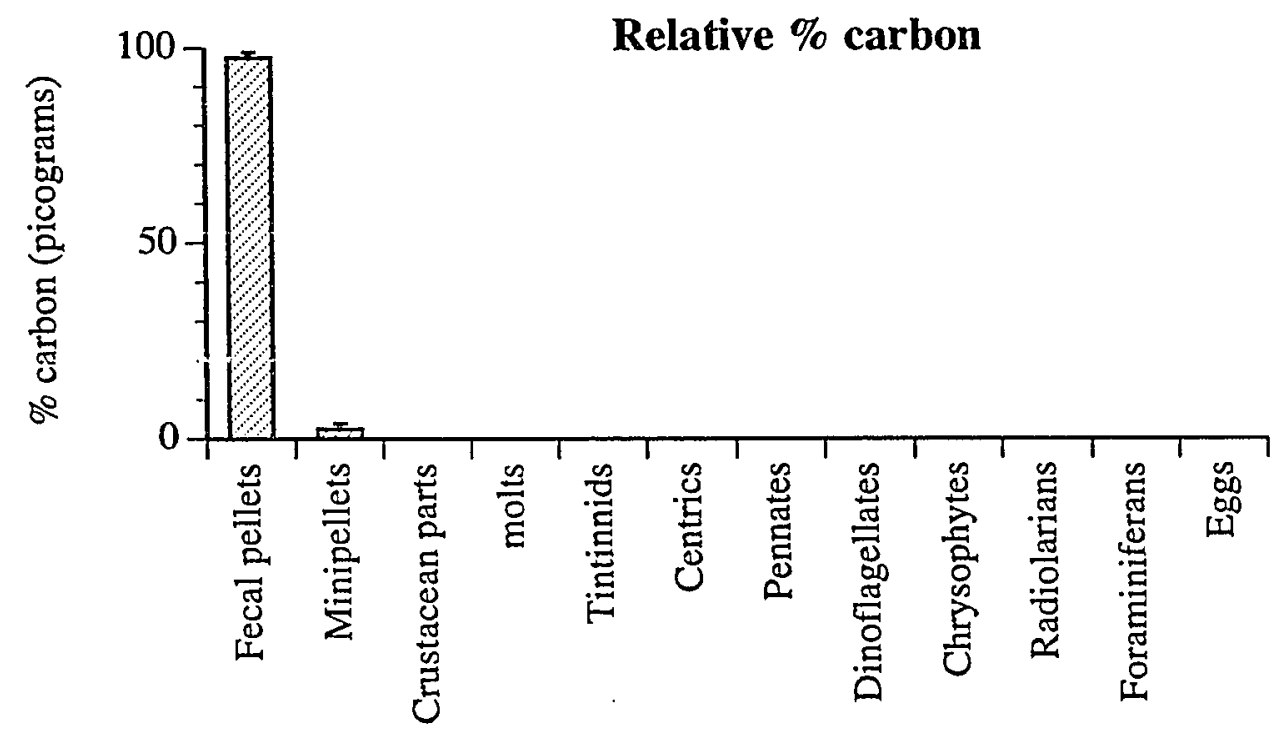

Figure 10. a) \& b) Relative \% volume of nutritious and non-nutritious food groups in the stomachs of $P$. meseres averaged over a one year period.c) The \% volume of nutritious food were converted into \%carbon (picograms) to show which food items $P$. meseres derived most of its nutrition. 
a.

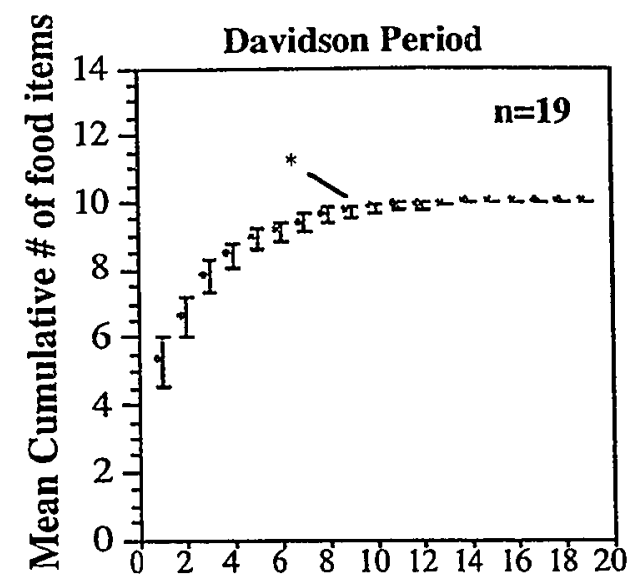

b.

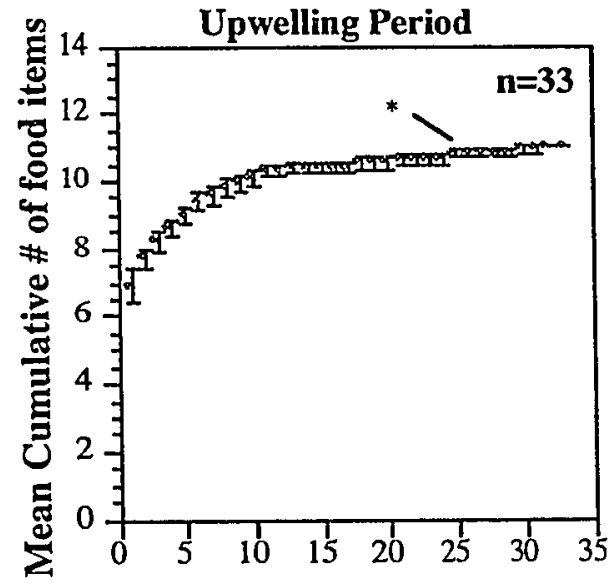

c.

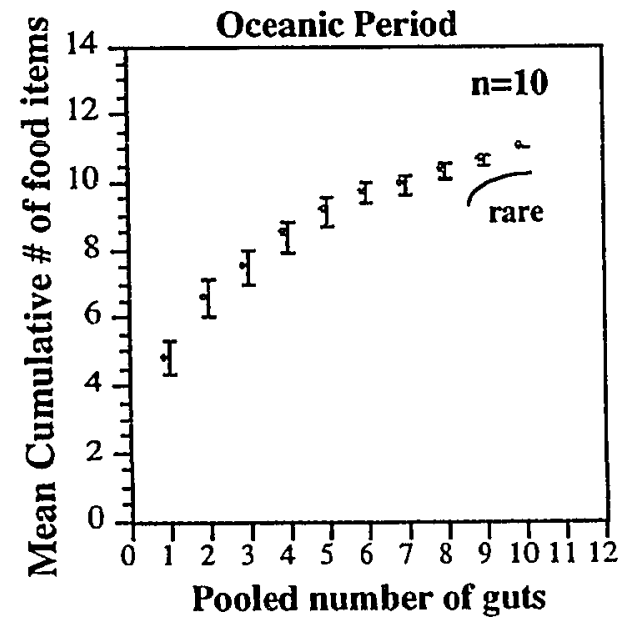

Figure 11. Adequacy of sampling over three oceanographic seasons in Monterey Bay; a) Davidson period (November-February), b) Upwelling period (March-August) and, c) Oceanic period (September-October). The "*" shows the pooled number of stomachs necessary to reach the stabilization of the curves. 
a

DAVIDSON PERIOD
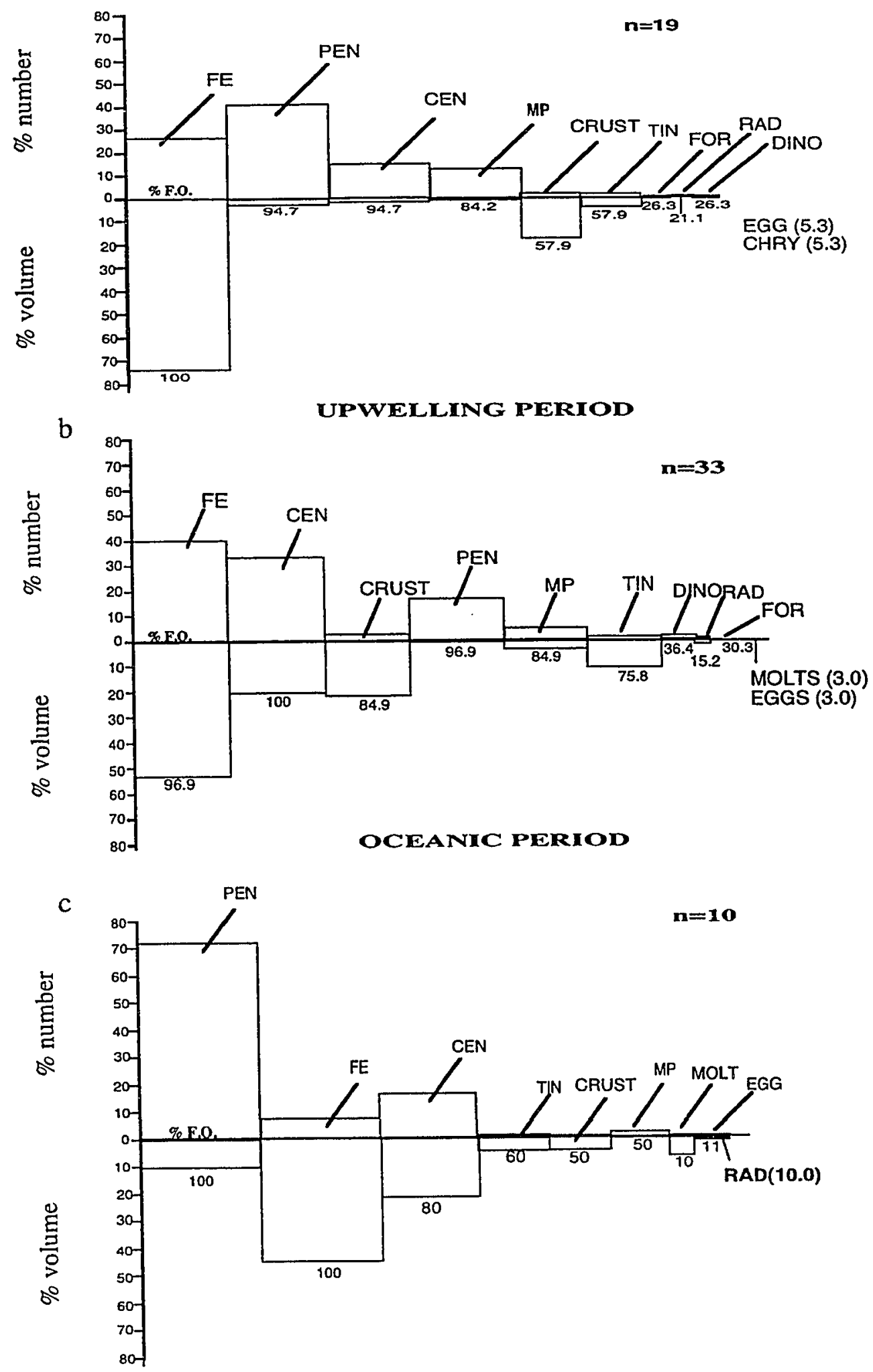

Figure 12. Composition of the major food groups in the stomachs of $P$.meseres for three oceanographic periods: 1) Davidson period (November-February), 2) Upwelling period (March-August) and, 3) Oceanic period (September-October). Abbreviations as for Figure 4. 
$\mathbf{a}$
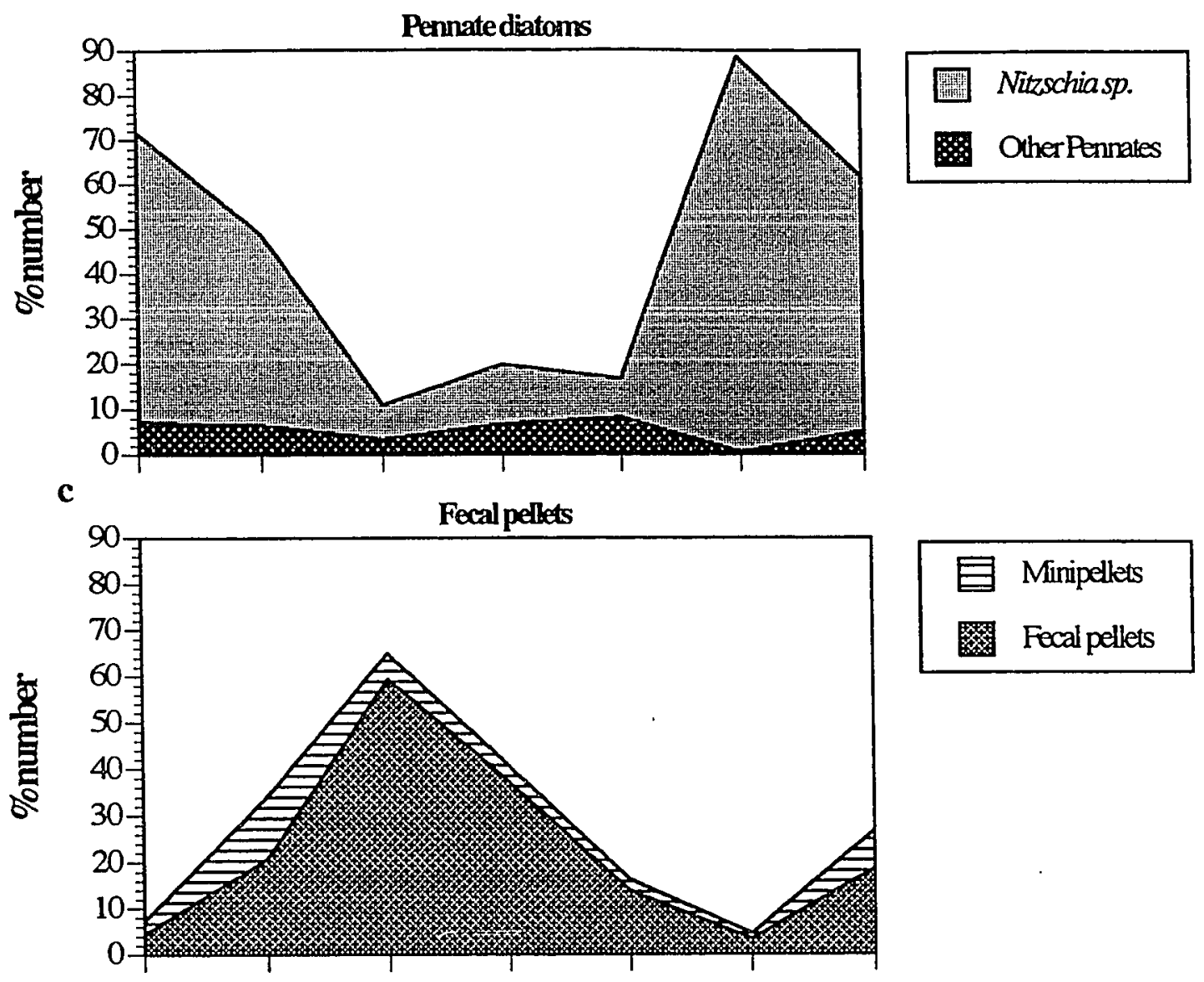

b

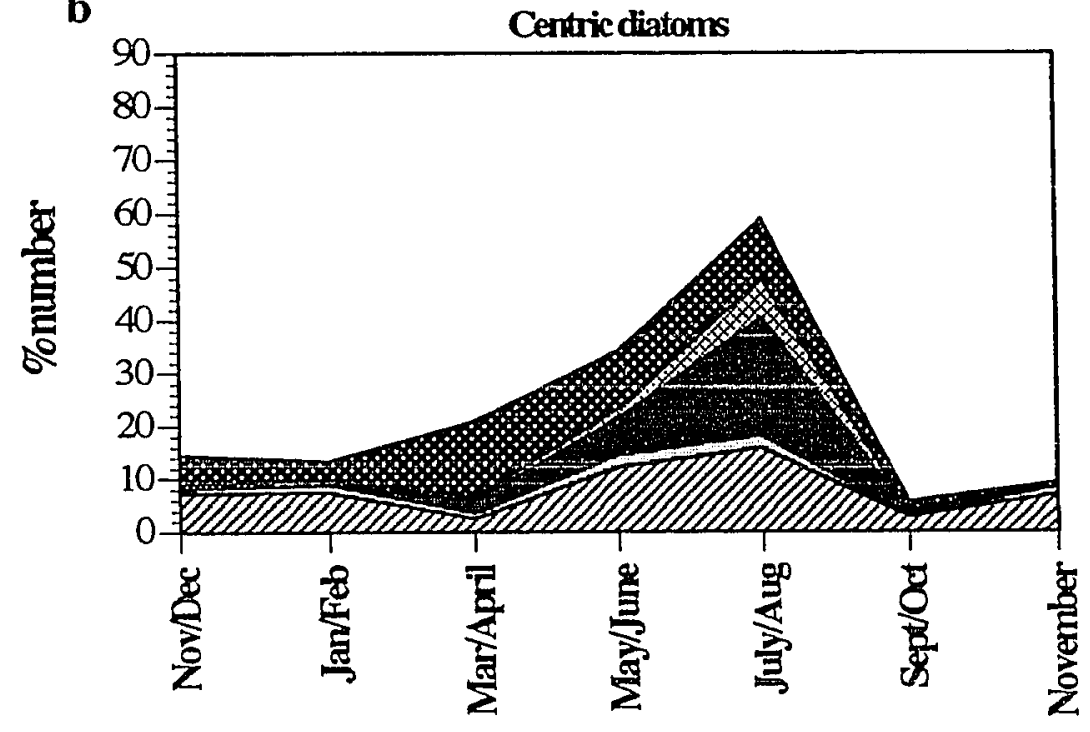

\begin{tabular}{|l|}
\hline Skeletonemaspp. \\
Chaetocerosspp. \\
Rhizasoleniaspp. \\
Thallasiosiraspp. \\
Other Centric diatoms
\end{tabular}

Figure 13. Relative abundance of the three most common food groups in the stomachs of $P$. meseres. Counts of each food type were averaged on a bimonthly basis and expressed as a percentage of the total stomach contents; a) Pennate diatoms were most abundant during September; b) Fecal pellets were most abundant during March and, c) Centric diatoms were most abundant during July and August. 

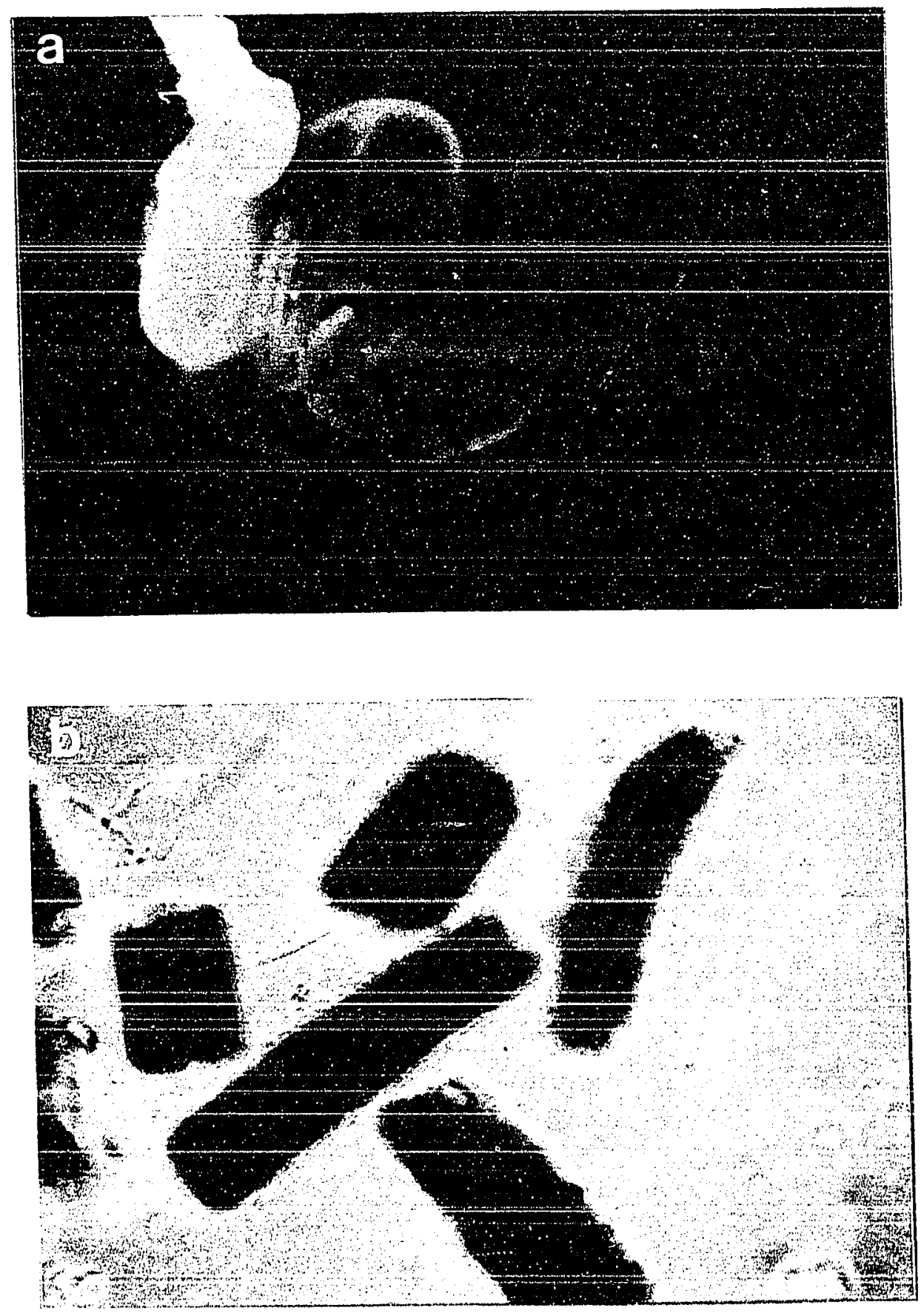

Figure 14. a) In March, the stomach cumtents of Peleobius meseres were packed with euphausiid fecal pellets from mouth (n anus. b) Compound microscope of euphausiid fecal pellets (320X magnilication). Pellets were cylindrical in shape with frayed ends and often had crustacean spines protruding out of the broken ends. 